\title{
Temporal variations in microbial activities and carbon turnover in subtidal sandy sediments
}

\author{
S. I. Böer ${ }^{1}$, C. Arnosti ${ }^{2}$, J. E. E. van Beusekom ${ }^{3}$, and A. Boetius ${ }^{1,4}$ \\ ${ }^{1}$ Microbial Habitat Group, Max Planck Institute for Marine Microbiology, Bremen, Germany \\ ${ }^{2}$ Dept. of Marine Sciences, University of North Carolina-Chapel Hill, Chapel Hill, NC, USA \\ ${ }^{3}$ Wadden Sea Station Sylt, Alfred Wegener Institute for Polar and Marine Research, List/Sylt, Germany \\ ${ }^{4}$ School of Engineering and Science, Jacobs University Bremen, Germany
}

Received: 8 September 2008 - Published in Biogeosciences Discuss.: 6 November 2008

Revised: 19 June 2009 - Accepted: 19 June 2009 - Published: 10 July 2009

\begin{abstract}
Temporal dynamics and vertical patterns in bacterial abundances and activities were studied in a shallow subtidal sand flat in the Sylt-Rømø Basin (North Frisian Wadden Sea, Germany). Extracellular enzymatic activities, bacterial carbon production and community respiration showed strong (factor of 4-5) temporal variations that were mostly related to seasonal temperature change and to changes in substrate availability. These temporal patterns in enzymatic activity were barely reflected in bacterial (200-400 $\mathrm{mmol} \mathrm{C} \mathrm{m}^{-2}$ ) and microphytobenthic biomass (800-1500 $\mathrm{mmol} \mathrm{C} \mathrm{m}^{-2}$ ) or the sedimentary carbohydrate inventory (1300-2900 $\mathrm{mmol} \mathrm{C} \mathrm{m}^{-2}$ ), suggesting that grazing controls the standing stocks of the microphytobenthic and bacterial assemblages. Despite their exposure to strong hydrodynamic forces such as tidal currents and wind-induced wave surge, the subtidal sandy sediments showed persistent vertical gradients in bacterial abundances, carbon production and extracellular enzymatic activities at all times. The vertical distribution of these parameters was tightly coupled to that of the microphytobenthos, dominated by diatoms. Despite the low organic carbon content typical for surgeexposed sandy sediments, high extracellular enzymatic activities and bacterial carbon production rates indicate a very active heterotrophic bacterial community, with a gross secondary productivity of $30-180 \mathrm{mmol} \mathrm{C}^{-2}$, and a biomass turnover time of 2-18 days. Our data suggest that this high activity is supported by the rapid flux of carbohydrates from microphytobenthic primary productivity. Accordingly, the
\end{abstract}

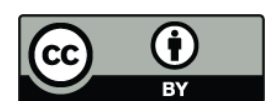

Correspondence to: S. I. Böer (sboeer@mpi-bremen.de) potential activities of enzymes hydrolyzing carbohydrates cover most of the total bacterial carbon demand during all seasons.

\section{Introduction}

Shelf sediments represent less than $10 \%$ of the ocean floor, but they contain the largest pool of particulate organic matter in the marine environment and play a major role in global carbon and nitrogen cycles (Jahnke, 2004). Shallow coastal ecosystems contribute substantially to oceanic carbon fixation via pelagic and benthic primary productivity (Wollast, 2002; Gattuso et al., 2006). The turnover of carbon in subtidal shelf sediments has been extensively investigated, however most studies focused on organic-rich, silty and muddy seafloors. Sandy sediments have long been considered as biochemically inert due to their low organic carbon content, and hence have been neglected in the marine carbon cycle (Boudreau et al., 2001). However, permeable sands are the dominant sediment type on continental shelves (Emery, 1968; Hall, 2002) and are important from biological and geological perspectives. High primary productivity has been measured recently in sandy sediments (Billerbeck et al., 2007), and organic matter mineralization rates have been found which are comparable to or even higher than rates in fine-grained, organic-rich sediments (D'Andrea et al., 2002; de Beer et al., 2005; Rusch et al., 2006).

The high mineralization rates are driven by photosynthetic production, either in the form of settling phytodetritus or via photosynthetic products excreted by the microphytobenthos (Goto et al., 2001; Rusch et al., 2003). Although burial

Published by Copernicus Publications on behalf of the European Geosciences Union. 
of phytoplankton detritus has been shown to stimulate benthic microbial activities (Meyer-Reil, 1987; van Duyl et al., 1992; Rooney-Varga et al., 2005), primary productivity by microphytobenthic algae (MPB) is recognized as the main source of organic carbon for benthic life in light-exposed coastal sediments (MacIntyre et al., 1996; Underwood and Kromkamp, 1999).

Carbon flux from microphytobenthic algae to other benthic microorganisms can be significant and rapid, as has been demonstrated by studies using isotope tracer incubations (Middelburg et al., 2000; Cook et al., 2007a). Large quantities of extracellular polymeric substances (EPS) are secreted by the MPB to promote their migration, adhesion to sediment particles and sediment cohesion (Hoagland et al., 1993; Underwood and Paterson, 2003). In addition, unbalanced growth under nutrient-depleted conditions may considerably increase the release of carbohydrates by photoautotrophs in order to maintain cell-nutrient balances (OrtegaCalvo and Stal, 1994; Smith and Underwood, 1998). In consequence, up to $70 \%$ of the carbon fixed may be excreted as EPS, rather than allocated to algal growth (Middelburg et al., 2000; de Brouwer and Stal, 2001) and serve as a major source of carbon to the benthic bacteria (Underwood and Kromkamp, 1999). The MPB, often dominated by benthic diatoms, and bacteria, are thus typically closely associated in biofilms on the sand grains (Huettel et al., 2003).

Previous studies of bacterial assemblages and their activities in permeable sediments (e.g. Staats et al., 2001a, b; Rusch et al., 2003; de Beer et al., 2005; Misic and Fabiano, 2005; Misic and Harriague, 2007) have focused mostly on intertidal areas, and/or had limited time or depth resolution, and thus could not resolve the interactions between the autotrophic and the heterotrophic components of the microbial communities in this habitat.

In the present study we focused on spatial, temporal and temperature-related variations in benthic microbial activity and the MPB-derived carbohydrate inventory on a shallow subtidal sand flat (Hausstrand) in the Sylt-Rømø Basin of the North Frisian Wadden Sea. Data were obtained from 6 sampling periods over the course of more than a year, covering a water temperature range of $1.5-18^{\circ} \mathrm{C}$. To test the hypothesis that microbial biomass reflects spatial and temporal variations in the distribution of the MPB and their carbohydrates, we measured bacterial biomass, photopigments (as a proxy for primary producer biomass), and total sedimentary carbohydrates as well as EDTA-extractable carbohydrates, which are quantitatively important substrates for the benthic microbial community of photosynthetically active sands. The effects of temperature, sediment depth and other factors controlling microbial activity (bacterial secondary production and enzymatic activities) were explored by multivariate analysis.

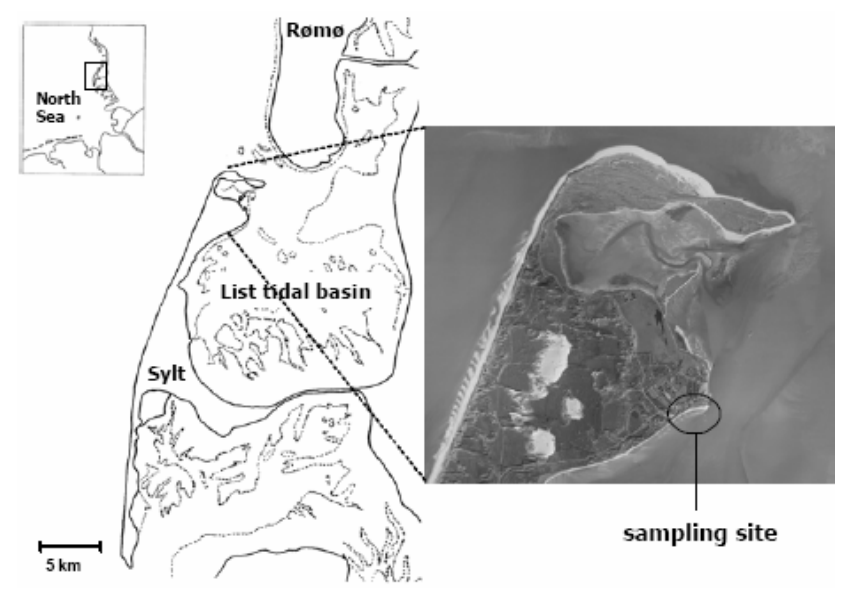

Fig. 1. Map showing the location of the Hausstrand sampling site in the Sylt-Rømø basin (also known as the List tidal basin) close to the island of Sylt in the North Frisian Wadden Sea, Germany (picture obtained from the Wadden Sea National Park Office SchleswigHolstein).

\section{Materials and methods}

\subsection{Study site}

\subsubsection{Site description}

The study site Hausstrand is located on the island of Sylt $\left(55^{\circ} 00^{\prime} 47.7^{\prime \prime} \mathrm{N}, 008^{\circ} 25^{\prime} 59.3^{\prime \prime} \mathrm{E}\right.$; Fig. 1$)$, where the temperature difference between summer and winter can be more than $20^{\circ} \mathrm{C}$ (Hedtkamp, 2005). The site is characterized by the strong hydrodynamic forces of tides and wind-induced waves, with a tidal amplitude of $\sim 2 \mathrm{~m}$. Water depth ranges between $0.5-2.5 \mathrm{~m}$, depending on weather and the tidal phase. Sediments consist of well to moderately well sorted silicate sand with a medium particle size of $350 \mu \mathrm{m}$. The permeability of the upper $15 \mathrm{~cm}$ of the sediments ranges between $1.01 \times 10^{-11} \mathrm{~m}^{2}$ and $3.36 \times 10^{-11} \mathrm{~m}^{2}$, with higher values in winter and spring compared to summer and autumn (Hedtkamp, 2005). Since the islands of Sylt and Røm $\varnothing$ are connected to the mainland by a causeway, the main water exchange takes place through the inlet to the North Sea. The Hausstrand sands have a low organic carbon concentration of $0.13 \%$ on average (Hedtkamp, 2005). Further information on the Sylt Rømø Basin (also known as the List tidal basin) are given by Gätje and Reise (1998) and van Beusekom and Reise (2008) and references therein.

\subsubsection{Sampling and sample processing}

Push cores $(3.6 \mathrm{~cm}$ inner diameter, $15-20 \mathrm{~cm}$ length) were collected in February, April, July and November 2005, and 1 and 27 March (labeled March I and March II) 2006 during low tide. In April and November, sampling was performed by scuba-diving, due to stormy weather and high water level. 
In November, the retrieved sediment cores included only the top $10 \mathrm{~cm}$ layer. Replicate cores $(8.4 \mathrm{~cm}$ inner diameter, $30 \mathrm{~cm}$ length) were also collected for measurement of benthic oxygen demand.

Ten replicate sediment cores from an area of $<20 \mathrm{~m}^{2}$ were sectioned at $1-\mathrm{cm}$ intervals down to $15 \mathrm{~cm}$ depth. Sediment slices from the same depth horizon were pooled and homogenized. The samples were processed in the laboratory adjacent to the Hausstrand field site (AWI station, List on Sylt) immediately after collection. Subsamples for the measurement of photopigments and carbohydrates were frozen immediately and stored at $-20^{\circ} \mathrm{C}$. The rest of the homogenized sediment was combined in $5-\mathrm{cm}$ intervals $(0-5,5-10$, and $10-15 \mathrm{~cm})$. For bacterial cell counts sediment was fixed in $2 \%$ formaldehyde/seawater solution; subsamples for the measurement of extracellular enzymatic activities (EEA) and bacterial carbon production $(\mathrm{BCP})$ were processed immediately. At all time points, additional push cores $(3.6 \mathrm{~cm}$ inner diameter, $15-$ $20 \mathrm{~cm}$ length) with silicon-covered injection holes were collected for measurements of laminarin hydrolysis. The cores were injected with $100 \mu \mathrm{l}$ of laminarin $(1.9 \mu \mathrm{mol}$ monomer equivalents $1^{-1}$ ) at depths of 1,5 , and $13 \mathrm{~cm}$, and incubated at in situ temperature in the dark.

\subsection{Rate measurements}

\subsubsection{Bacterial carbon production (BCP)}

BCP was estimated by measuring the rate of [Methyl- ${ }^{3} \mathrm{H}$ ] thymidine (TdR) incorporation into DNA (Fuhrman and Azam, 1982; Moriarty and Pollard, 1990). Sediment slurries (1:1 sediment: sterile-filtered seawater; $n=4-5$ per depth interval) amended with $\mathrm{TdR}$ were incubated for $1.5-4 \mathrm{~h}$ at near in situ temperature, and TdR incorporation was stopped by adding $100 \mu \mathrm{l}$ of $37 \%$ formaldehyde. Killed controls received formaldehyde prior to incubation. A time course and concentration experiment was conducted at the beginning of the study to ensure that all measurements were carried out in the initial linear period of incorporation of label into DNA and that isotope dilution by de novo synthesis of thymidine was insignificant (Moriarty, 1990). Extractions followed a modification of Findley et al. (1984) and Michel and Bloem (1993). BCP was calculated using a conversion factor of $2 \times 10^{6}$ cells produced per pmol thymidine incorporated (Findley, 1993), and a carbon conversion factor of $20 \mathrm{fg} \mathrm{C}$ cell $^{-1}$ (Fuhrman and Azam, 1982).

\subsubsection{Extracellular enzyme activities (EEA)}

\section{Potential exoenzymatic activity}

Hydrolysis rates were measured in slurries using 4-methylumbelliferone- (MUF-) and 4-methylcoumarinyl7-amide- (MCA-) labeled model substrates, which capture the activities of exoenzymes that cleave the terminal ends of polymer chains. They are widely used (e.g. Hoppe, 1983; Hoppe et al., 1988; Boetius, 1995; Boetius and Lochte, 1996a, b), facilitating comparison between studies, but the extent to which they represent the activities of enzymes on true polymers is uncertain (Warren, 1996). Potential hydrolytic activities of $\alpha$-glucosidase, $\beta$-glucosidase, chitobiase, lipase, phosphatase and aminopeptidase were measured using the MUF-labeled substrate analogs MUF- $\alpha$-D-glucoside, MUF- $\beta$-D-glucopyranoside, MUF-Nacetyl- $\beta$-glucosamine, MUF-stearate, MUF-phosphate and MCA-labeled leucine (all obtained from Sigma-Aldrich, Munich, Germany), respectively. For each depth interval $(0-5,5-10$ and $10-15 \mathrm{~cm})$ and substrate, five replicate 0.5 $\mathrm{ml}$ sub-samples of homogenized sediment from 10 pooled cores were diluted 1:10 with sterile filtered seawater. The substrates were dissolved in ethylene glycol monomethyl ether and added to the slurry at a final concentration of $0.5 \mathrm{mM}$. The samples were then agitated at in situ temperature in the dark. Shortly after the start of the time course experiment, $1 \mathrm{ml}$ of the sample was removed and added to $2 \mathrm{ml}$ of sterile-filtered seawater amended with $250 \mu \mathrm{l}$ of borate buffer ( $\mathrm{pH}$ 10.0). After centrifugation, the supernatant was transferred into disposable UV-cuvettes and the fluorescence of the enzymatically released MUF and MCA was measured ( $445 \mathrm{~nm}$ emission, $365 \mathrm{~nm}$ exitation). A second measurement was performed after $2-4 \mathrm{~h}$ of incubation time. Pre-experiments were conducted prior to the start of the study to confirm that the final concentrations of MUF and MCA substrates generally represented substrate saturation levels and yielded maximum velocities. Hydrolytic activity was calculated from the increase of fluorescence over time calibrated via standards of both MUF and MCA. Since the fractions of the bacterial community that produce specific enzymes are unknown, cell-specific EEA was calculated as extracellular enzymatic activity divided by the total number of cells.

\section{Potential endoenzymatic activity}

Fluorescently labeled (FLA-) macromolecules (e.g. polysaccharides) can be used to measure the activities of endoenzymes (mid-chain cleaving enzymes) (Arnosti, 1995), and may better mimic the degradation of complex macromolecules in natural settings. Here, hydrolysis of laminarin was measured using the method of Arnosti (1995, 2003). Laminarin is an energy storage product of diatoms (Lee, 1980; Painter, 1983) and thus naturally abundant in coastal sands. Laminarin and fluorescenamine (isomer II) were purchased from Sigma, and fluorescently labeled laminarin was synthesized after Glabe et al. (1983) as described in Arnosti (1995, 2003). Potential hydrolysis rates of laminarin were measured in intact sediment cores by injection of $1.9 \mu \mathrm{mol}$ monomer equivalents of laminarin at $1 \mathrm{~cm}, 5 \mathrm{~cm}$ and $13 \mathrm{~cm}$ depths. These measures were used to extrapolate to the average activity in the $0-5,5-10$ and 
$10-15 \mathrm{~cm}$ layers. One core was left without laminarin and served as a blank sample. All cores were incubated at in situ temperature in the dark in an upright position. After $\sim 24, \sim 48$ and $\sim 72 \mathrm{~h}$ incubation at in situ temperature, 2-3 replicate cores were sacrificed and sectioned at $2-\mathrm{cm}$ intervals. Hydrolysis of substrate was found to be nearly complete by $24 \mathrm{~h}$, so all of the rates being reported here are derived from triplicate $24 \mathrm{~h}$ incubations. Pore water was purged from the sediment with nitrogen, as described by Billerbeck et al. (2006), filtered through $0.2 \mu \mathrm{m}$ pore size filters, and stored at $-20^{\circ} \mathrm{C}$ until analysis. One core was sectioned immediately after injection as the time zero sample. The molecular weight distribution of hydrolyzed polysaccharides was determined via low-pressure gel permeation chromatography (GPC) with fluorescence detection, as described in Arnosti (2003). Potential hydrolysis rates were calculated based on the molecular weight distribution of laminarin hydrolysis products in each sample as described by Arnosti $(1995,2003)$.

All laminarinase rates in this study may represent minimum potential rates, since the fluorescently labeled substrate competes with naturally occurring laminarin for enzyme active sites. Usually, FLA-laminarin is added equal to 100 $500 \%$ of the total dissolved carbohydrates in order to measure hydrolysis at substrate saturation level. The concentration of dissolved interstitial carbohydrates in the sands was not measured in this study. FLA-laminarin was added in concentrations of 2.3-5.4 mmol glucose $\mathrm{L}^{-1}$, which represents $200-800 \%$ of the pool of EDTA-extractable carbohydrates. However, since total carbohydrate concentrations were rather high (see results below), competition with naturally available laminarin cannot be excluded, especially in the diatomdominated surface sediments.

Alderkamp et al. (2006) estimated that ca. $13 \%$ of the bacteria from North Sea coastal waters are capable of producing laminarinase. However, it is not known if this result also applies to sediments and how this ratio changes with time or location. In order to allow comparison with cell-specific MUF-/MCA-enzymatic activities, cell-specific laminarinase activities were calculated by dividing laminarinase activities by the total number of bacterial cells.

\subsubsection{Benthic oxygen consumption}

Gross benthic community respiration rates were estimated ex situ via incubation of intact sediment cores. The gasand air-tight cores ("chambers") were fitted with sampling ports and a magnetic stirrer and contained approximately $1 \mathrm{~L}$ sediment and $0.75 \mathrm{~L}$ of overlying water. The chambers were maintained at in situ temperature in a dark cold room. The overlying water in the chambers was stirred carefully at a speed of $\sim 20 \mathrm{rpm}$. Oxygen concentrations in the water were determined by duplicate Winkler titrations (Winkler, 1888; Grasshoff et al., 1983) according to the procedure of Strickland and Parsons (1972), of samples withdrawn from the chambers over a 5-point timecourse. The benthic oxygen consumption rates were calculated from the averages of oxygen decrease over time according to Thorbergsdóttir et al. (2004). As the stirring speed was at the low end of advection of oxygenated water through Hausstrand sands, the rates presented here likely represent an underestimation of in situ respiration rates.

\subsection{Bacterial counts and concentration measurements}

\subsubsection{Cell numbers}

Bacterial abundances were estimated by epifluorescence microscopy after staining with Acridine Orange (AO) using a modification of the method of Hobbie et al. (1977). Prior to staining, the fixed samples $(0.5 \mathrm{ml}$ sediment per replicate) were centrifuged for $15 \mathrm{~min}$ at $4000 \mathrm{rpm}$ and the fixative was removed and set aside. One milliliter of the removed fixative was placed back onto the sample and the slurry was sonicated for $4 \mathrm{~min}$ with an ultrasonic disintegrator while keeping the vial on ice (van Duyl and Kop, 1994). After the sand grains settled, the supernatant containing the cells was transferred to another vial. The remaining sediment was washed six times, each time with $1 \mathrm{ml}$ of the fixative, which was thereafter combined with the cell suspension. Two 1-ml sub-samples (1:1000 final dilution) were filtered onto $0.2 \mu \mathrm{m}$ black polycarbonate filters and stained with $\mathrm{AO}$ solution (final concentration $0.01 \%$ ) for $3 \mathrm{~min}$. Subsequently, the filters were rinsed with $1 \mathrm{ml}$ of citrate buffer and bacteria enumerated by epifluorescence microscopy $(\times 1000)$. Final counts represent averages of 6 filters $(2$ filters from 3 replicate field samples), with 10-20 grids counted on each filter with at least 1000 cells per filter.

\subsubsection{Determination of photopigments}

Triplicates of approximately $1 \mathrm{~g}$ of freeze-dried and homogenized sediment from each sediment layer were mixed with $7.5 \mathrm{ml}$ of $90 \%$ acetone and extracted in the dark at $4^{\circ} \mathrm{C}$ for $24 \mathrm{~h}$. Prior to measurement, the samples were centrifuged at $4000 \mathrm{rpm}$ for $10 \mathrm{~min}$. The supernatant was transferred to quarz cuvettes and the absorbance of the extract was measured at 665 and $750 \mathrm{~nm}$ before and after acidification with $10 \% \mathrm{HCl}$. Chlorophyll $a$ and phaeophytine concentrations were calculated according to Lorenzen (1967). Based on known sediment water contents, concentrations were converted to $\mu \mathrm{g} \mathrm{cm}^{-3}$ wet sediment. A carbon to chlorophyll $a$ conversion factor of 34 (Dijkman, as cited in Evrard et al., 2008) was used to estimate MPB biomass.

\subsubsection{Carbohydrate analysis}

Total and EDTA-extractable carbohydrates were quantified using the phenol-sulfuric acid assay (Dubois et al., 1956; Herbert et al., 1971), according to Underwood et al. (1995). All measurements were done in triplicates. For measurement 
of EDTA-extractable carbohydrates, $100 \mathrm{mg}$ of lyophilized and homogenized sediment was extracted with $5 \mathrm{ml}$ of $0.1 \mathrm{M}$ $\mathrm{Na}_{2}$-EDTA for $15 \mathrm{~min}$ at $20^{\circ} \mathrm{C}$. Following centrifugation at $4000 \mathrm{rpm}$ for $15 \mathrm{~min}, 2 \mathrm{ml}$ of the supernatant was transferred to combusted glass vials and $1 \mathrm{ml}$ of $5 \%$ aqueous phenol (w/v) was added, immediately followed by $5 \mathrm{ml}$ of concentrated $\mathrm{H}_{2} \mathrm{SO}_{4}$. After $10 \mathrm{~min}$, the samples were carefully homogenized and incubated another $30 \mathrm{~min}$. Absorbance was measured against a reagent blank at $485 \mathrm{~nm}$. Measurements were calibrated against a curve made using glucose as a standard, so concentrations are expressed as microgram glucose equivalents. For the measurement of total carbohydrates, $50 \mathrm{mg}$ of lyophilized and homogenized sediment was suspended in $2 \mathrm{ml}$ of distilled $\mathrm{H}_{2} \mathrm{O}$, and then analyzed as above. Based on known sediment water contents, concentrations were converted to $\mu \mathrm{g} \mathrm{ml}^{-1}$ wet sediment.

\subsection{Statistical analysis}

Error estimates represent standard deviations from the averages, based on replicate measurements as described above for each method. Correlations between all environmental variables were calculated using the Pearson's correlation coefficient for all samples that included carbohydrate measurements. All data, except for depth and temperature, were $\log _{10}$-transformed to normalize their distribution. Data was normalized to standard mean $=0$ and a standard deviation of 1 prior to computation of the Pearson's correlation coefficients. $\mathrm{P}$-values were corrected for multiple testing using the Bonferroni correction (Ramette, 2007).

The relationship between environmental variables was studied in more detail by multivariate statistics using the software package CANOCO for Windows 4.5 (terBraak and Smilauer, 1998). A principal component analysis (PCA) was used to reduce the dimensionality of the complex data set. PCA is an orthogonal linear transformation method that converts a number of potentially correlated variables into a smaller number of independent variables, the so-called principal components, while maintaining most of the original variability in the data. The first principal component accounts for the greatest variability in the data and each succeeding component explains as much of the remaining variability as possible.

\section{Results}

\subsection{Bacterial cell numbers and growth rates}

Total cell numbers and bacterial carbon production (BCP) were highest in the upper $0-5 \mathrm{~cm}$ sediment layer and decreased with depth (Table 1). Cell numbers ranged between 1.7 and $2.9 \times 10^{9}$ cells $\mathrm{cm}^{-3}$ wet sediment in the $0-5 \mathrm{~cm}$ layer, representing a bacterial biomass of $2.8-$ $4.8 \mathrm{mmol} \mathrm{C} \mathrm{L}^{-1}$, based on a conversion factor of $20 \mathrm{fgC}$ cell $^{-1}$ (Fuhrman and Azam, 1982). BCP ranged between
0.43 and $2.29 \mathrm{mmol} \mathrm{C} \mathrm{L}^{-1} \mathrm{~d}^{-1}$. Turnover time of the bacterial community biomass was calculated to be $2.1-8.6 \mathrm{~d}$ in the $0-5 \mathrm{~cm}$ layer, with fastest turnover in July and slowest turnover in November. Bacterial biomass and BCP generally followed temperature, with maximum values in July (Fig. 2). However, despite the fact that $\mathrm{BCP}$ rates and bacterial turnover time in the upper sand layer were ca. 4 times higher in July than in preceding or following sampling months, temporal changes in bacterial biomass were less pronounced and varied by less than a factor of 2 .

\subsection{Potential extracellular enzyme activities}

Enzyme activities measured using MUF- and MCAsubstrate amended sediment slurries decreased in the order aminopeptidase $>$ phosphatase $>$ chitobiase, $\beta$ glucosidase $>\alpha$-glucosidase $>$ lipase. Hydrolysis rates in the upper sediment layer ranged between $0.7-4.5 \mu \mathrm{mol} \mathrm{L}^{-1}$ wet sediment $\mathrm{h}^{-1}$ ( $\alpha$-glucosidase $), 1.1-7.8 \mu \mathrm{mol} \mathrm{L}^{-1} \mathrm{~h}^{-1}(\beta$ glucosidase), $1-9.9 \mu \mathrm{mol} \mathrm{L}^{-1} \mathrm{~h}^{-1}$ (chitobiase) (Fig. 3a-c); 9-40 $\mu \mathrm{mol} \mathrm{L}^{-1} \mathrm{~h}^{-1}$ (phosphatase), 0.03-0.8 $\mu \mathrm{mol} \mathrm{L}^{-1} \mathrm{~h}^{-1}$ (lipase) and 13-101 $\mu \mathrm{mol} \mathrm{L}^{-1} \mathrm{~h}^{-1}$ (aminopeptidase). Similar to bacterial abundances and growth rates, all EEA showed a clear depth trend. With few exceptions, hydrolytic activities decreased by factors of 1.5 to 6 with increasing sediment depth. The decrease was more pronounced between the middle and deepest layer than between the surface and middle layer. Only for chitobiase and lipase activities was this depth trend inverted in a few cases, such that the EEA was higher at $5-10 \mathrm{~cm}$ depth than at $0-5 \mathrm{~cm}$ depth. All EEA showed strong temporal patterns and generally followed the temperature curve, with highest activities measured in July and lowest activities on winter sampling dates (Fig. 3). However, in the top layers chitobiase $(0-10 \mathrm{~cm})$ and phosphatase $(0-5 \mathrm{~cm})$ activities were lower in April than in February despite a temperature increase of $5.4^{\circ} \mathrm{C}$. Cell-specific MUF- and MCA-EEA ranged between $0.2-2.2 \mathrm{amol} \mathrm{h}^{-1}$ cell $^{-1}$ for chitobiase, between $0.12-0.98 \mathrm{amol} \mathrm{h}^{-1}$ cell $^{-1}$ for $\alpha$-glucosidase, between $0.18-1.7 \mathrm{amol} \mathrm{h}^{-1}$ cell $^{-1}$ for $\beta$ glucosidase, between $0.02-0.24 \mathrm{amol} \mathrm{h}^{-1}$ cell $^{-1}$ for lipase, between 1.9-22 $\mathrm{amol} \mathrm{h}^{-1}$ cell $^{-1}$ for aminopeptidase and between 1.24 and $8.8 \mathrm{amol} \mathrm{h}^{-1}$ cell $^{-1}$ for phosphatase. The temporal and depth-related trends of the cell-specific EEA were comparable to those of total hydrolysis rates; however cell-specific EEA did not decrease as rapidly with depth as total EEA.

Enzymatic hydrolysis of laminarin showed depth and seasonal trends comparable to hydrolytic rates of exoenzymes acting on carbohydrates (Fig. 3). Laminarin hydrolysis rates generally decreased with increasing sediment depth except for March II samples, where rates were higher at a depth of $5 \mathrm{~cm}$ than at $1 \mathrm{~cm}$. Laminarin hydrolysis also followed the temperature curve and reached maximum values in July, although seasonal differences were not as pronounced as for MUF- and MCA-labeled substrates. Hydrolysis rates ranged 

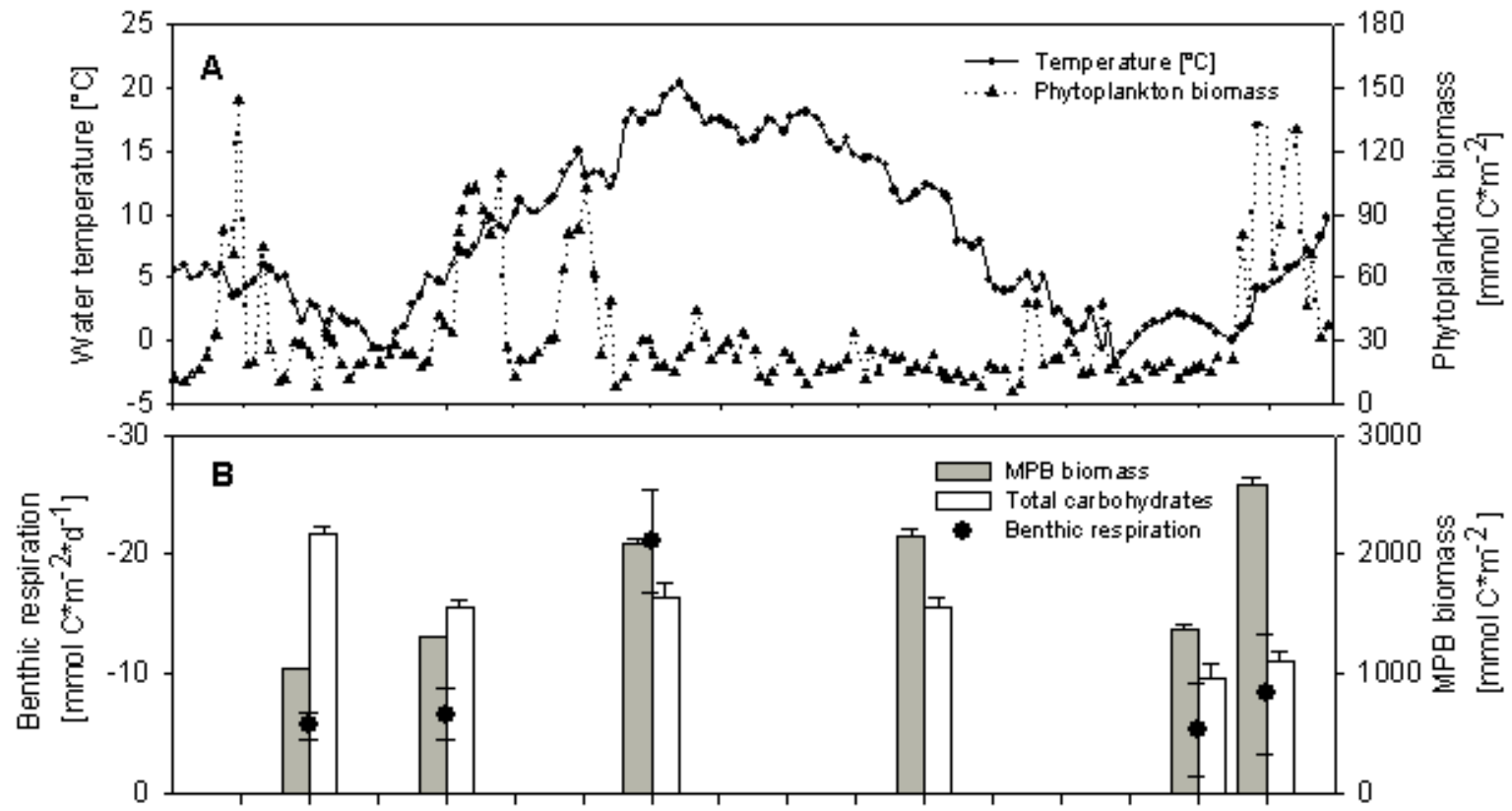

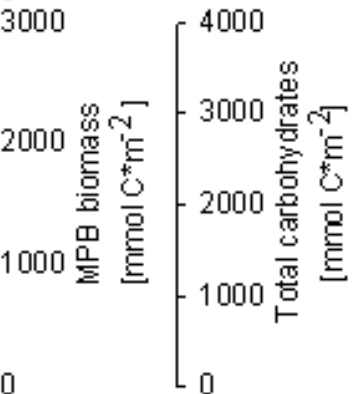
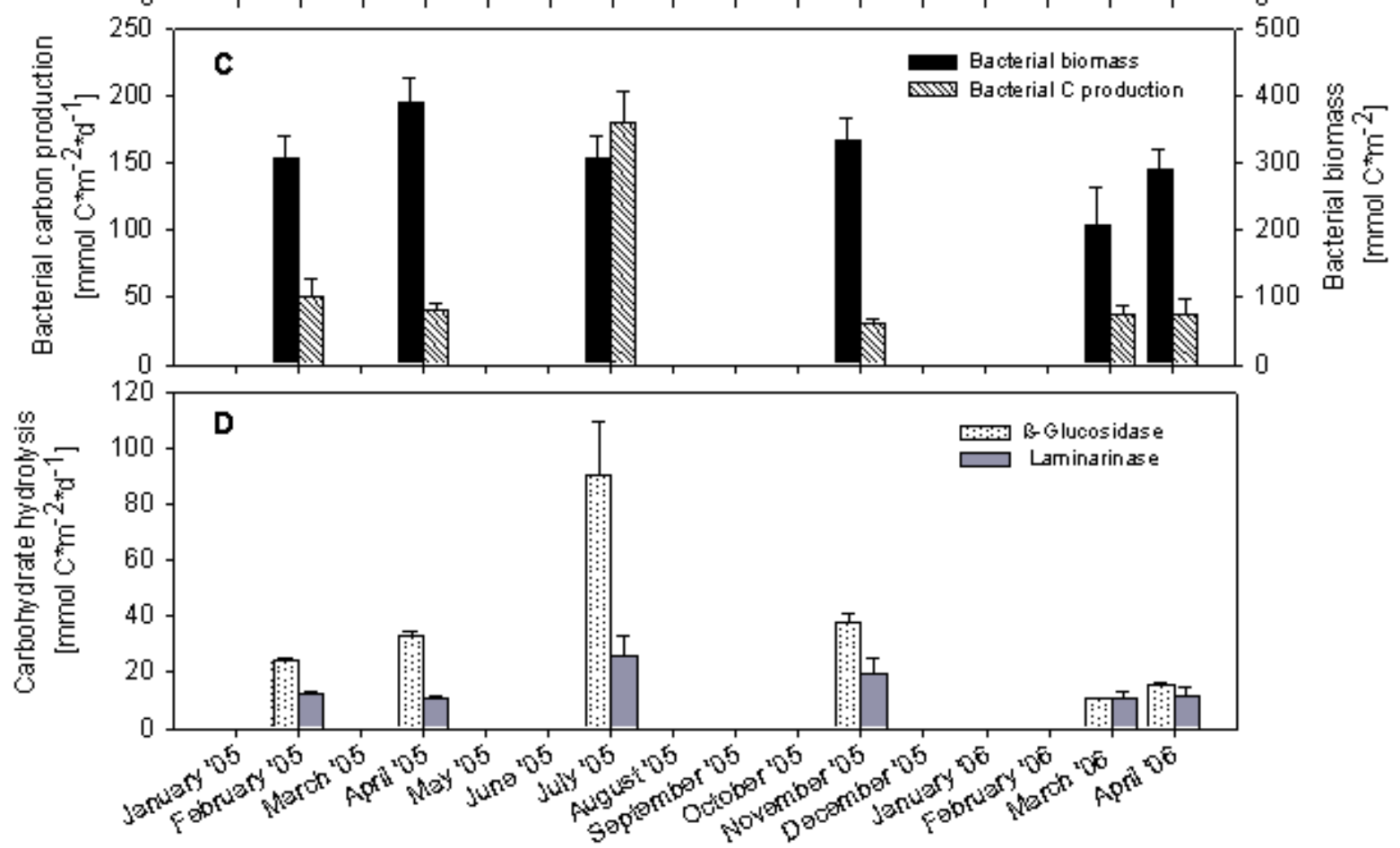

Fig. 2. Seasonal patterns of standing stocks and fluxes in the Hausstrand sands. All values were converted to carbon units and integrated over the upper $10 \mathrm{~cm}$ of sediment except for the water column data (integrated over the average depth of the water column of $2 \mathrm{~m}$ ). Error bars represent standard deviations. (A) Phytoplankton biomass (triangles) and water temperature (circles). (B) MPB biomass (grey bars, $n=3$ ), total carbohydrates (white bars, $n=3$ ) and benthic oxygen consumption rates (circles, $n=4$ ). (C) Bacterial biomass (black bars, $n=6$ ), bacterial carbon production rates measured via thymidine incorporation (striped bars, $n=4-5$ ). (D) C-hydrolysis by $\beta$-glucosidase activity (dotted bars, $n=5$ ) and by laminarinase activity (dark grey bars, $n=2-3$ ). 
Table 1. Depth-related and temporal changes in carbon fractions and enzymatic carbon hydrolysis in Hausstrand sediments.

\begin{tabular}{|c|c|c|c|c|c|c|c|c|c|c|c|c|}
\hline Date & $\begin{array}{l}\text { Sed. } \\
\text { layer } \\
(\mathrm{cm})\end{array}$ & $\begin{array}{l}\text { Bact. cell } \\
\text { numbers } \\
\left(\times 10^{9} \mathrm{~cm}^{-3}\right)\end{array}$ & $\begin{array}{l}\text { Bacterial } \\
\text { biomass } \\
\left(\mathrm{mmol} \mathrm{CL}^{-1}\right) \\
{[\mathrm{a}]}\end{array}$ & $\begin{array}{l}\text { Bact. C } \\
\text { prod. } \\
\left(\mathrm{mmolCL}^{-1} \mathrm{~d}^{-1}\right)\end{array}$ & $\begin{array}{l}\text { Bact. } \\
\text { turnover } \\
\text { time (d) }\end{array}$ & $\begin{array}{l}\text { MPB } \\
\text { biomass } \\
\left(\mathrm{mmol} \mathrm{CL}^{-1}\right) \\
{[\mathrm{b}]}\end{array}$ & $\begin{array}{l}\text { Total } \\
\text { carbs } \\
\left(\mathrm{mmol} \mathrm{CL}^{-1}\right)\end{array}$ & $\begin{array}{l}\text { EDTA extr. } \\
\text { carbs } \\
\left(\mathrm{mmol} \mathrm{CL}^{-1}\right)\end{array}$ & $\begin{array}{l}\text { C-hydrolysis by } \\
\text { Chitobiase } \\
\left(\mathrm{mmol} \mathrm{C} \mathrm{L}^{-1} \mathrm{~d}^{-1}\right) \\
{[\mathrm{c}]}\end{array}$ & $\begin{array}{l}\text { C-hydrolysis by } \\
\beta \text {-Glucosidase } \\
\left(\mathrm{mmol} \mathrm{CL} \mathrm{L}^{-1} \mathrm{~d}^{-1} \text { ) }\right. \\
{[\mathrm{d}]}\end{array}$ & $\begin{array}{l}\text { C-hydrolysis by } \\
\alpha \text {-Glucosidase } \\
\left(\mathrm{mmol} \mathrm{C} \mathrm{L}{ }^{-1} \mathrm{~d}^{-1} \text { ) }\right. \\
{[\mathrm{d}]}\end{array}$ & $\begin{array}{l}\text { C-hydrolysis by } \\
\text { Laminarinase } \\
\left(\mathrm{mmol} \mathrm{CL}^{-1} \mathrm{~d}^{-1}\right) \\
{[\mathrm{e}]^{*}}\end{array}$ \\
\hline 8-Feb-05 & $0-5$ & $2.4 \pm 0.26$ & 4.0 & $0.62 \pm 0.07$ & 6.5 & 16.4 & $33 \pm 1.1$ & $7.1 \pm 0.40$ & $0.38 \pm 0.03$ & $0.34 \pm 0.01$ & $0.22 \pm 0.00$ & $0.13 \pm 0.002$ \\
\hline \multirow[t]{2}{*}{$(1.5 \times C)$} & $5-10$ & $1.3 \pm 0.13$ & 2.2 & $0.38 \pm 0.19$ & 5.8 & 4.6 & $25 \pm 0.9$ & $4.6 \pm 0.31$ & $0.55 \pm 0.21$ & $0.14 \pm 0.03$ & $0.08 \pm 0.02$ & $0.12 \pm 0.007$ \\
\hline & $10-15$ & $0.9 \pm 0.07$ & 1.5 & $0.23 \pm 0.07$ & 6.5 & 2.0 & N.A. & N.A. & $0.05 \pm 0.01$ & $0.03 \pm 0.00$ & $0.02 \pm 0.01$ & 0 \\
\hline 8-Apr-05 & $0-5$ & $2.0 \pm 0.28$ & 3.3 & $0.44 \pm 0.06$ & 7.5 & 19.2 & $25 \pm 0.9$ & $6.6 \pm 0.59$ & $0.36 \pm 0.04$ & $0.47 \pm 0.04$ & $0.25 \pm 0.06$ & $0.13 \pm 0.006$ \\
\hline \multirow{2}{*}{$(7 \times C)$} & $5-10$ & $1.4 \pm 0.13$ & 2.3 & $0.35 \pm 0.05$ & 6.6 & 7.0 & $17 \pm 0.7$ & $4.6 \pm 1.18$ & $0.23 \pm 0.02$ & $0.19 \pm 0.01$ & $0.09 \pm 0.03$ & $0.09 \pm 0.003$ \\
\hline & $10-15$ & $0.6 \pm 0.08$ & 1.0 & $0.23 \pm 0.05$ & 4.3 & 1.3 & N.A. & N.A. & $0.05 \pm 0.01$ & $0.05 \pm 0.00$ & $0.03 \pm 0.01$ & $0.01 \pm 0.001$ \\
\hline 2-Jul-05 & $0-5$ & $2.9 \pm 0.17$ & 4.8 & $2.29 \pm 0.34$ & 2.1 & 18.1 & $25 \pm 2.0$ & $4 \pm 0.50$ & $1.89 \pm 0.51$ & $1.13 \pm 0.08$ & $0.65 \pm 0.06$ & $0.26 \pm 0.105$ \\
\hline \multirow[t]{2}{*}{$(18 \times C)$} & $5-10$ & $2.0 \pm 0.28$ & 3.3 & $1.32 \pm 0.13$ & 2.5 & 6.1 & $19 \pm 1.4$ & $1.9 \pm 0.72$ & $0.47 \pm 0.33$ & $0.67 \pm 0.10$ & $0.22 \pm 0.03$ & $0.25 \pm 0.049$ \\
\hline & $10-15$ & $1.6 \pm 0.12$ & 2.7 & $0.05 \pm 0.08$ & 5.4 & 1.4 & $14 \pm 1.5$ & $1.8 \pm 1.01$ & $0.12 \pm 0.09$ & $0.18 \pm 0.04$ & $0.05 \pm 0.03$ & $0.11 \pm 0.067$ \\
\hline 9-Nov-05 & $0-5$ & $2.3 \pm 0.14$ & 3.8 & $0.44 \pm 0.02$ & 8.6 & 17.5 & $24 \pm 1.0$ & $4 \pm 0.64$ & $0.68 \pm 0.03$ & $0.44 \pm 0.05$ & $0.28 \pm 0.04$ & $0.2 \pm 0.041$ \\
\hline \multirow{2}{*}{$(11 \times \mathrm{C})$} & $5-10$ & $1.7 \pm 0.26$ & 2.8 & $0.16 \pm 0.05$ & 17.5 & 7.5 & $18 \pm 1.1$ & $2.2 \pm 0.27$ & $0.38 \pm 0.08$ & $0.31 \pm 0.03$ & $0.13 \pm 0.01$ & $0.19 \pm 0.064$ \\
\hline & $10-15$ & N.A. & N.A. & N.A. & N.A. & N.A. & N.A. & N.A. & N.A. & N.A. & N.A. & N.A. \\
\hline 1-Mar-06 & $0-5$ & $1.7 \pm 0.61$ & 2.8 & $0.43 \pm 0.05$ & 6.5 & 12.9 & $17 \pm 1.8$ & $5.9 \pm 2.23$ & $0.42 \pm 0.03$ & $0.15 \pm 0.01$ & $0.11 \pm 0.03$ & $0.14 \pm 0.050$ \\
\hline \multirow[t]{2}{*}{$(2 \times C)$} & 5-10 & $0.8 \pm 0.07$ & 1.3 & $0.30 \pm 0.10$ & 4.3 & 3.1 & $9 \pm 1.0$ & $3.6 \pm 0.58$ & $0.14 \pm 0.02$ & $0.06 \pm 0.01$ & $0.03 \pm 0.01$ & $0.07 \pm 0.004$ \\
\hline & $10-15$ & $0.6 \pm 0.06$ & 0.9 & $0.17 \pm 0.06$ & 5.3 & 1.3 & $8 \pm 0.9$ & $2.9 \pm 1.31$ & $0.19 \pm 0.03$ & $0.04 \pm 0.01$ & $0.01 \pm 0.00$ & $0.08 \pm 0.047$ \\
\hline \multirow{3}{*}{$\begin{array}{l}\text { 27-Mar-06 } \\
(4 \times C)\end{array}$} & $0-5$ & $2.1 \pm 0.16$ & 3.5 & $0.46 \pm 0.12$ & 7.6 & 21.3 & $19 \pm 0.9$ & $2.9 \pm 0.48$ & $0.19 \pm 0.01$ & $0.24 \pm 0.01$ & $0.15 \pm 0.01$ & $0.07 \pm 0.021$ \\
\hline & $5-10$ & $1.4 \pm 0.18$ & 2.3 & $0.30 \pm 0.10$ & 7.7 & 8.7 & $11 \pm 0.9$ & $1.7 \pm 0.13$ & $0.24 \pm 0.05$ & $0.08 \pm 0.00$ & $0.05 \pm 0.00$ & $0.16 \pm 0.053$ \\
\hline & $10-15$ & $0.5 \pm 0.04$ & 0.9 & $0.19 \pm 0.06$ & 4.7 & 1.1 & $4 \pm 0.8$ & $1.2 \pm 0.33$ & $0.04 \pm 0.01$ & $0.03 \pm 0.00$ & $0.01 \pm 0.00$ & $0.06 \pm 0.057$ \\
\hline
\end{tabular}

[a] Conversion factor: $20 \mathrm{fg}$ cell $^{-1}$ (Fuhrman and Azam, 1982)

[b] Conversion factor: 34 (Dijkman, as cited in Evrard, 2007)

[c] Carbon conversion factor: 8

[d] Carbon conversion factor: 6 (Hoppe, 1993)

[e] Carbon conversion factor: 6 (Hoppe, 1993)

* Rates measured at 0-2, 2-4 and 12-14 cm

between $0.5-1.8 \mu \mathrm{mol}$ glucose $\mathrm{L}^{-1}$ wet sediment $\mathrm{h}^{-1}$ at $1 \mathrm{~cm}$ depth, 0.5-1.7 $\mu \mathrm{mol}$ glucose $\mathrm{L}^{-1} \mathrm{~h}^{-1}$ at $5 \mathrm{~cm}$ depth and 0 $0.7 \mu \mathrm{mol}$ monomer $\mathrm{L}^{-1} \mathrm{~h}^{-1}$ at $13 \mathrm{~cm}$ depth. Rates in intact cores were a factor of $\sim 4$ lower than exoenzymatic activities measured in sediment slurries (e.g. $\beta$-glucosidase), in accordance with the factor of 2 to 6 difference in hydrolysis rates in homogenized sediments compared to intact cores (Arnosti and Holmer, 2003). However, a high fraction of the injected FLA-polysaccharide was hydrolyzed after $24 \mathrm{~h}$ incubation: $20-70 \%$ in surface sediments, $19-68 \%$ in mid-depth sediments, and 0-29\% in deep sediments, with highest fraction turned over in July and lowest in March. Hence, at least the rates in surface and mid-layer sediments may be significantly underestimated. Cell-specific laminarinase rates ranged between $0.25-0.61 \mathrm{amol} \mathrm{h}^{-1} \mathrm{cell}^{-1}$ at 1 $\mathrm{cm}$ depth, $0.44-0.86 \mathrm{amol} \mathrm{h}^{-1}$ cell $^{-1}$ at $5 \mathrm{~cm}$ depth and 0 $0.97 \mathrm{amol} \mathrm{h}^{-1}$ cell $^{-1}$ at $13 \mathrm{~cm}$ sediment depth, which is a similar range as for the exo-acting enzymes. No clear trend with depth was observed. Cell-specific laminarinase rates were higher at $5 \mathrm{~cm}$ than at $1 \mathrm{~cm}$ and in March also higher at 13 than at $5 \mathrm{~cm}$ sediment depth, underlining the potentially high competition with naturally occurring substrates at the sediment surface.

\subsection{Chlorophyll pigments and microphytobenthic biomass}

As derived from the chlorophyll $a$ concentrations, a high MPB standing stock was present throughout the study period, with values ranging between $6.5-9.1 \mu \mathrm{g} \mathrm{cm}^{-3}$ wet sediment in the top centimeter. Based on average chlorophyll $a$ concentrations between 4.5 and $7.5 \mu \mathrm{g} \mathrm{cm}^{-3}$ in the top 5 centimeters (Fig. 4a), a MPB biomass of $13-21 \mathrm{mmol} \mathrm{CL}^{-1}$ was estimated. Highest concentrations were measured in April 2005 and in March (II) 2006. On each of these occasions, a pelagic diatom bloom was beginning to develop in the area. However, the integrated standing stock in the water column is only $0.5-7 \%$ of the integrated standing stock of the MPB (Fig. 2). The benthic chlorophyll $a$ peaks in spring thus most likely resulted from enhanced growth of the MPB rather than from phytodetritus sedimentation and burial. Over the investigated time period, temporal variation remained below a factor of 2 (Fig. 2). The vertical distribution was characterized by constantly decreasing but high chlorophyll $a$ concentrations ( $>1.5 \mu \mathrm{g} \mathrm{cm}^{-3}$ wet sediment) down to $5-8 \mathrm{~cm}$. In deeper sediment layers chlorophyll $a$ decreased to concentrations below $1.5 \mu \mathrm{g} \mathrm{cm}^{-3}$ wet sediment but was still detectable (Fig. 4a).

Phaeophytine also tended to decrease with depth, although there was no clear vertical profile. Concentrations stayed below $0.9 \mu \mathrm{g} \mathrm{cm}^{-3}$ wet sediment, and varied especially in the upper $10 \mathrm{~cm}$ of sediment. The ratio between chlorophyll $a$ and phaeophytine ranged between 8 and 75:1 in the upper $5 \mathrm{~cm}$ of sediment and decreased to ratios between 1.7 and $11: 1$ in the $10-15 \mathrm{~cm}$ layer, indicating the dominance of living algae over phytodetritus. There was no obvious seasonal trend, but concentrations appeared to slighty decrease from the 1 st to the last sampling date.

\subsection{Benthic oxygen consumption}

Total benthic oxygen consumption in dark incubations (gross respiration) was closely coupled to temperature, ranging between 5 and $21 \mathrm{mmol} \mathrm{C} \mathrm{m}^{-2} \mathrm{~d}^{-1}$ and varying seasonally with highest values in July 2005 (Fig. 2). The total benthic oxygen consumption measured here likely significantly 

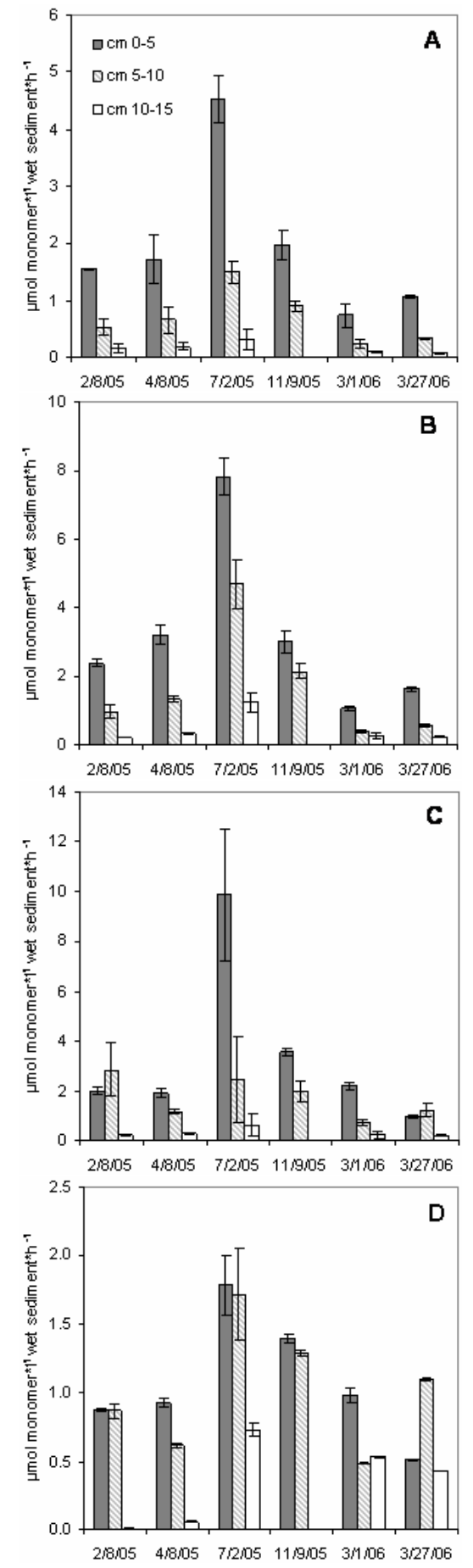

Fig. 3. Depth-related and temporal patterns in potential extracellular enzymatic activities of (A) $\alpha$-glucosidase (MUF- $\alpha$-Dglucoside), (B) $\beta$-glucosidase (MUF- $\beta$-D-glucoside), (C) chitobiase (MUF-N-acetyl- $\beta$-glucosamine), and (D) laminarinase (fluorescently labeled laminarin).
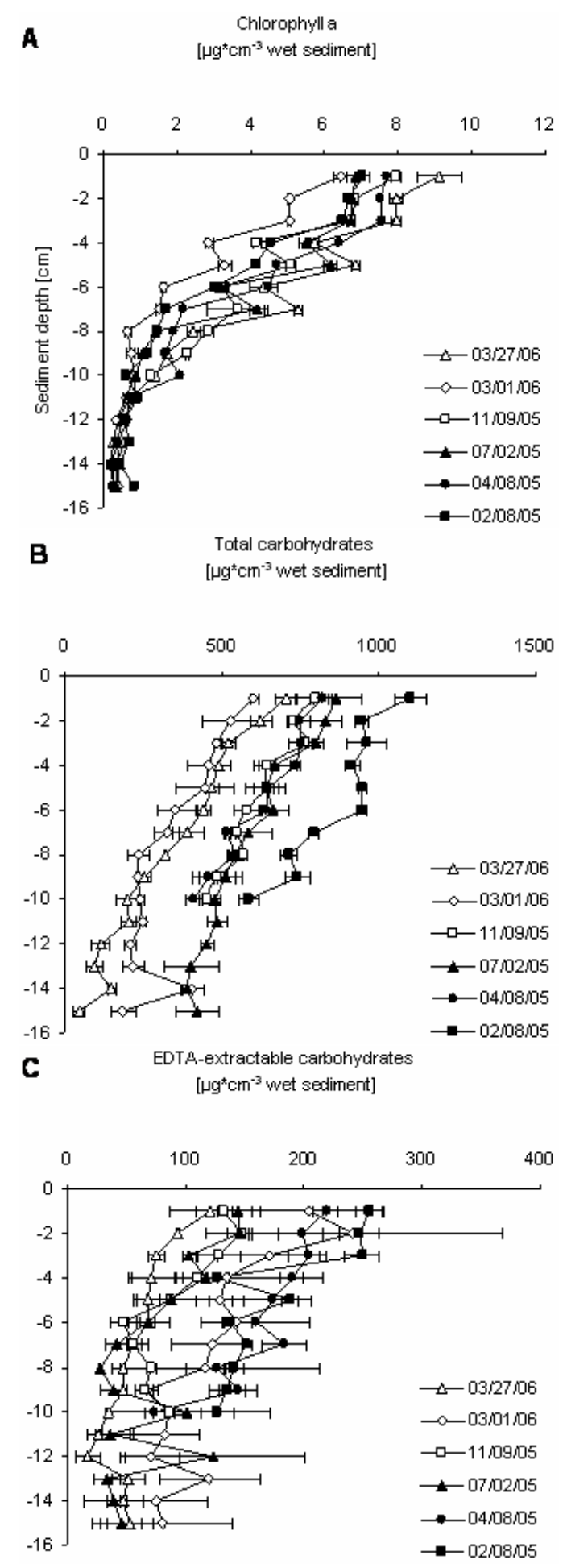

Fig. 4. Depth-related and temporal changes in (A) benthic chlorophyll $a$; (B) total carbohydrate and (C) EDTA-extractable carbohydrate concentrations. 
underestimated in situ benthic oxygen consumption due to the low stirring speeds applied. Hence, seasonal trends can be compared, but carbon flux calculated from total oxygen consumption is probably underestimated (see below).

\subsection{Carbohydrate inventory}

Two carbohydrate fractions were measured, total carbohydrates, which include intracellular and extracellular carbohydrates (soluble as well as particle-bound), and the EDTAextractable carbohydrate fraction that includes all extracellular soluble carbohydrates. Both fractions showed a clear depth trend (Fig. 4). Concentrations of total carbohydrates were highest in the uppermost centimeter $(4-6 \mu \mathrm{mol}$ glucose equivalents $\mathrm{cm}^{-3}$ wet sediment) and decreased almost linearly to $10 \mathrm{~cm}$ depth $\left(1-3 \mu \mathrm{mol}\right.$ glucose equivalents $\left.\mathrm{cm}^{-3}\right)$ and $15 \mathrm{~cm}\left(0.3-2 \mu \mathrm{mol}\right.$ glucose equivalents $\left.\mathrm{cm}^{-3}\right)$. There was no seasonal trend (Figs. 2, 4). Rather, total carbohydrate concentrations in the upper $10 \mathrm{~cm}$ constantly decreased from February 2005 until end of March 2006. EDTA-extractable carbohydrates followed the same vertical patterns, with values between $0.7-1.4 \mu \mathrm{mol}$ glucose equivalents $\mathrm{cm}^{-3}$ wet sediment in the uppermost centimeter and between 0.2 $0.7 \mu \mathrm{mol}$ glucose equivalents $\mathrm{cm}^{-3}$ at $10 \mathrm{~cm}$ depth $(0.2-$ $0.4 \mu \mathrm{mol}$ glucose equivalents $\mathrm{cm}^{-3}$ at $15 \mathrm{~cm}$ depth; Fig. 4). The EDTA-extractable carbohydrates constituted between 13 and $37 \%$ of the total carbohydrate pool in the upper $10 \mathrm{~cm}$; this share did not change considerably with increasing sediment depth. The contribution of EDTA-extractable carbohydrates to the total carbohydrate pool was highest in April 2005 and in March (I) 2006, averaging 27\% and 37\%, respectively. These sampling dates, together with February 2005, were also when the highest concentrations of EDTAextractable carbohydrates were measured.

\subsection{Statistical analysis of spatial and temporal varia- tions}

The permeable subtidal sands of the island of Sylt in the Northern Wadden Sea constitute a highly dynamic environment, exposed to strong tidal currents and frequent storm events. Nevertheless, strong and persistent depth-patterns in bacterial abundances, BCP, EEA, and carbohydrate inventories were found over an annual cycle. Despite the low organic carbon content of the sediments, high extracellular enzyme activities and bacterial carbon production showed that the microbial community was very active. These high microbial activities were found to be tightly coupled to the productivity of the microphytobenthos. The dominating factors explaining the spatial (vertical) and temporal variations of bacterial activities were evaluated by Pearson Correlation (Table 4) and Principal Component Analysis (PCA; Fig. 6). Temporal variation was clearly related to temperature changes (1st axis); and spatial variations (vertical gradients) were best explained by the spatial distribution of the microphytobenthos (2nd axis). Bacterial cell abundances, benthic chlorophyll $a$, and phaeophytine as well as total and EDTA extractable carbohydrates showed a strong negative relationship with sediment depth (statistically significant only for chlorophyll a and phaeophytine), likely a result of photosynthetic production being confined to the upper few millimeters of the sediment and mixing with depth. Bacterial abundances were significantly correlated with benthic chlorophyll $a$ and hydrolytic activities of most extracellular enzymes (Table 4; Fig. 6). Phosphatase and aminopeptidase activities were also directly correlated with chlorophyll $a$ and phosphatase also with depth, and most enzymes were correlated with each other. Variation in bacterial carbon production was significantly correlated to $\alpha$-glucosidase, $\beta$-glucosidase and lipase activities. Lipase varied mainly temporally and this variation was strongly linked to the water temperature. The nature of the correlations identified via statistical analysis is examined in greater detail below.

\section{Discussion}

\subsection{Benthic primary production and respiration}

Permeable coastal sediments are characterized by a high biomass of benthic diatoms, which represent the main source of organic matter (Nelson et al., 1999; D'Andrea et al., 2004). At the Hausstrand site, benthic net primary productivity exceeds pelagic net primary productivity with rates around $53 \mathrm{mmol} \mathrm{C} \mathrm{m}^{-2} \mathrm{~d}^{-1}\left(\sim 19 \mathrm{~mol} \mathrm{C} \mathrm{m}^{-2} \mathrm{yr}^{-1}\right.$; Wenzhöfer, pers. comm.) compared to $4-18 \mathrm{mmol} \mathrm{C} \mathrm{m}^{-2} \mathrm{yr}^{-1}$ (integrated over a mean water depth of $2 \mathrm{~m}$ ) in the water-column of the Sylt-Rømø-basin (Asmus et al., 1998; Loebl et al., 2007). Assuming a flushing rate between $160-500 \mathrm{~L} \mathrm{~m}^{-2} \mathrm{~d}^{-1}$ (de Beer et al., 2005) of the upper $5 \mathrm{~cm}$ of sands by the overlying water, the input of the pelagic spring bloom would be less than a third of the microphytobenthic (MPB) standing stock. Furthermore, the MPB standing stock at the Hausstrand is relatively constant throughout the year (Hedtkamp, 2005). It produces large amounts of extracellular polymeric substances (EPS), mainly composed of carbohydrates, which has been suggested to be the main source of energy and labile organic carbon to the bacterial community (MacIntyre et al., 1996; Underwood and Kromkamp, 1999). In addition, the benthic meiofauna may benefit from these exudates (van Oevelen et al., 2006), and may also feed directly on the bacteria and diatoms (Epstein, 1997; Cahoon, 1999). The MPB, bacteria and other microorganisms form a biofilm community in the surface sands, presumably causing a tight coupling between variations in primary productivity, fluxes of exudates and remineralization. This close linkage allows for a particularly rapid carbon flow from the autotrophic to the heterotrophic compartment at sunlight-exposed, sandy sediment sites (Middelburg et al., 2000). 
Table 2. Temporal changes in total bacterial carbon demand and carbon turnover by the benthic bacterial community at the Hausstrand. Areal estimates are based on integration over the top $10 \mathrm{~cm}$.

\begin{tabular}{|c|c|c|c|c|c|c|}
\hline & 8-Feb-05 & 8-Apr-05 & 2-Jul-05 & 9-Nov-05 & 1-Mar-06 & 27-Mar-06 \\
\hline MPB Biomass [mmol $\left.\mathrm{C} \mathrm{m}^{-2}\right]$ & 1045 & 1309 & 1211 & 1249 & 796 & 1499 \\
\hline Bacterial biomass $\left[\mathrm{mmol} \mathrm{C} \mathrm{m}^{-2}\right]$ & 308 & 283 & 408 & 333 & 208 & 292 \\
\hline Total carbohydrates $\left[\mathrm{mmol} \mathrm{C} \mathrm{m}^{-2}\right]$ & 2889 & 2090 & 2195 & 2071 & 1302 & 1472 \\
\hline EDTA extractable carbohydrates $\left[\mathrm{mmol} \mathrm{C}^{-2}\right]$ & 586 & 556 & 292 & 309 & 472 & 227 \\
\hline Bacterial carbon production $\left[\mathrm{mmol} \mathrm{C} \mathrm{m}{ }^{-2} \mathrm{~d}^{-1}\right]$ & 50 & 40 & 180 & 30 & 37 & 38 \\
\hline Total bacterial $\mathrm{C}$ demand $\left[\mathrm{mmol} \mathrm{C} \mathrm{m}{ }^{-2} \mathrm{~d}^{-1}\right]^{\mathrm{a}}$ & 100 & 79 & 360 & 61 & 73 & 76 \\
\hline Total potential $\mathrm{C}$ generated from hydrolysis of carbohydrates $\left[\mathrm{mmol} \mathrm{C} \mathrm{m}{ }^{-2} \mathrm{~d}^{-1}\right]^{\mathrm{b})}$ & 98 & 91 & 277 & 130 & 57 & 59 \\
\hline Coverage of total bacterial $\mathrm{C}$ demand by $\mathrm{C}$ hydrolysis of carbohydrates $[\%]^{\mathrm{a}}$ & 99 & 115 & 77 & 215 & 77 & 78 \\
\hline Total carbohydrate $\mathrm{C}$ fraction potentially consumed by bacterial community $\left[\% \mathrm{~d}^{-1}\right]^{\mathrm{a}}$ & 3 & 4 & 16 & 3 & 6 & 5 \\
\hline EDTA extractable carbohydrate $C$ fraction potentially consumed by bacterial community $\left[\% \mathrm{~d}^{-1}\right]^{\mathrm{a}}$ & 17 & 14 & 124 & 20 & 15 & 34 \\
\hline MPB biomass fraction potentially consumed by bacterial community $\left[\% \mathrm{~d}^{-1}\right]^{\mathrm{a}}$ & 10 & 6 & 30 & 5 & 9 & 5 \\
\hline
\end{tabular}

a Growth yield 50\% (Moriarty et al., 1985)

${ }^{\mathrm{b}}$ Sum of $\alpha$-glucosidase, $\beta$-glucosidase, chitobiase and laminarinase

The benthic carbon metabolism at Hausstrand can be estimated from rates of total benthic oxygen consumption as measured by chamber incubations (e.g. Canfield et al., 1993). Because of the high permeability of the sediments and the low stirring speeds used in our chamber incubations, however, oxygen consumption rates in this study were likely underestimated. Previous in situ chamber incubations at the Hausstrand site in summer 2004 yielded oxygen consumption rates of $25 \mathrm{mmol} \mathrm{C} \mathrm{m}^{-2} \mathrm{~d}^{-1}$ and $56 \mathrm{mmol} \mathrm{C} \mathrm{m}^{-2} \mathrm{~d}^{-1}$, when measured at stirring speeds of 20 and $160 \mathrm{rpm}$, respectively, indicating that oxygen consumption rates under advective conditions may exceed those under diffusive conditions by a factor of 2.3 (Cook et al., 2007b). Applying this factor to the rates measured here $\left(\leq 21 \mathrm{mmol} \mathrm{C} \mathrm{m}^{-2} \mathrm{~d}^{-1}\right)$ would yield values close to estimates by Cook et al. (2007b), Heip et al. (1990) and Cramer (1990), which are at the lower range of values estimated for total microbial respiration (30$180 \mathrm{mmol} \mathrm{C} \mathrm{m}^{-2} \mathrm{~d}^{-1}$ ), assuming a carbon assimilation efficiency of 50\%. Cramer (1990) suggested that meiofauna and macrofauna are only responsible for $1-15 \%$ of the total benthic respiration in North Sea sediments.

\subsection{Contribution of sedimentary carbohydrates to ben- thic metabolism}

To estimate the potential turnover of total and EDTAextractable carbohydrates by extracellular hydrolysis, carbohydrate concentrations were divided by the sum of potential activities of $\alpha$-glucosidase, $\beta$-glucosidase, chitobiase and laminarinase in the $0-5,5-10$, and $10-15 \mathrm{~cm}$ depth intervals. As shown in Fig. 5a, in July in the $0-5 \mathrm{~cm}$ depth interval, $5-15 \%$ of the total carbohydrate pool, and almost the entire EDTA-extractable carbohydrate pool could have been hydrolyzed by these enzymes on a daily basis. Even in the $10-15 \mathrm{~cm}$ depth interval, complete hydrolysis of the EDTA-extractable pool would be possible on the order of 5 days. Potential hydrolysis efficiency was considerably lower in March (I) than in July, but still ranged from 4-12\% of the EDTA-extractable pool on a daily basis (Fig. 5b). These rapid turnover rates indicate a high flux of EDTA-extractable carbohydrates throughout the year (Table 2). The seasonal variations are most likely explained by the higher hydrolytic activities in summer. Turnover time of total carbohydrates at the Hausstrand is rapid compared to sandy beach sediments of the Ligurian Sea ( 3-619 days, Misic and Fabiano, 2005).

Potential hydrolytic activities of extracellular exoenzymes measured in the present study were as high as those observed in muddy, organic-rich sediments of the Kiel Bight (Meyer-Reil, 1986) and Ems-Dollard estuary (van Duyl et al., 1999). Laminarinase activities, although potentially underestimated in the surface layer due to substrate competition (see below), are comparable to rates measured in microbially active, organic-rich sediments in a range of other environments, including the Skagerrak, Cape Lookout Bight NC, and Svalbard (Hoppe et al., 2002; Arnosti and Holmer, 2003; Arnosti and Jørgensen, 2006). A high fraction of the total added FLA-polysaccharides was hydrolyzed within $24 \mathrm{~h}$, resulting in an underestimation of hydrolysis rates, particularly in the surface and mid-depths, especially during the July sampling period. Furthermore, differences in assay method played a role, since a comparison of hydrolysis for a range of FLA-labeled polymers demonstrated that rates were 2-6 times more rapid in homogenized sediments compared to intact cores (Arnosti and Holmer 2003).

Turnover of different constituents of organic matter ultimately derived from MPB photosynthetic production can also be estimated and related to carbon demand by bacteria and by the whole benthic community. Figure 2 and Table 2 show a comparison of the major carbon inventories in the sands. Assuming a gross phototrophic primary production of $100 \mathrm{mmol} \mathrm{Cm}^{-2} \mathrm{~d}^{-1}$ in the top $10 \mathrm{~cm}$ of sand by adding up net benthic photosynthesis (Hausstrand data from May 2003, Wenzhöfer et al., unpublished) and average respiration rates (assuming a bacterial growth yield of 

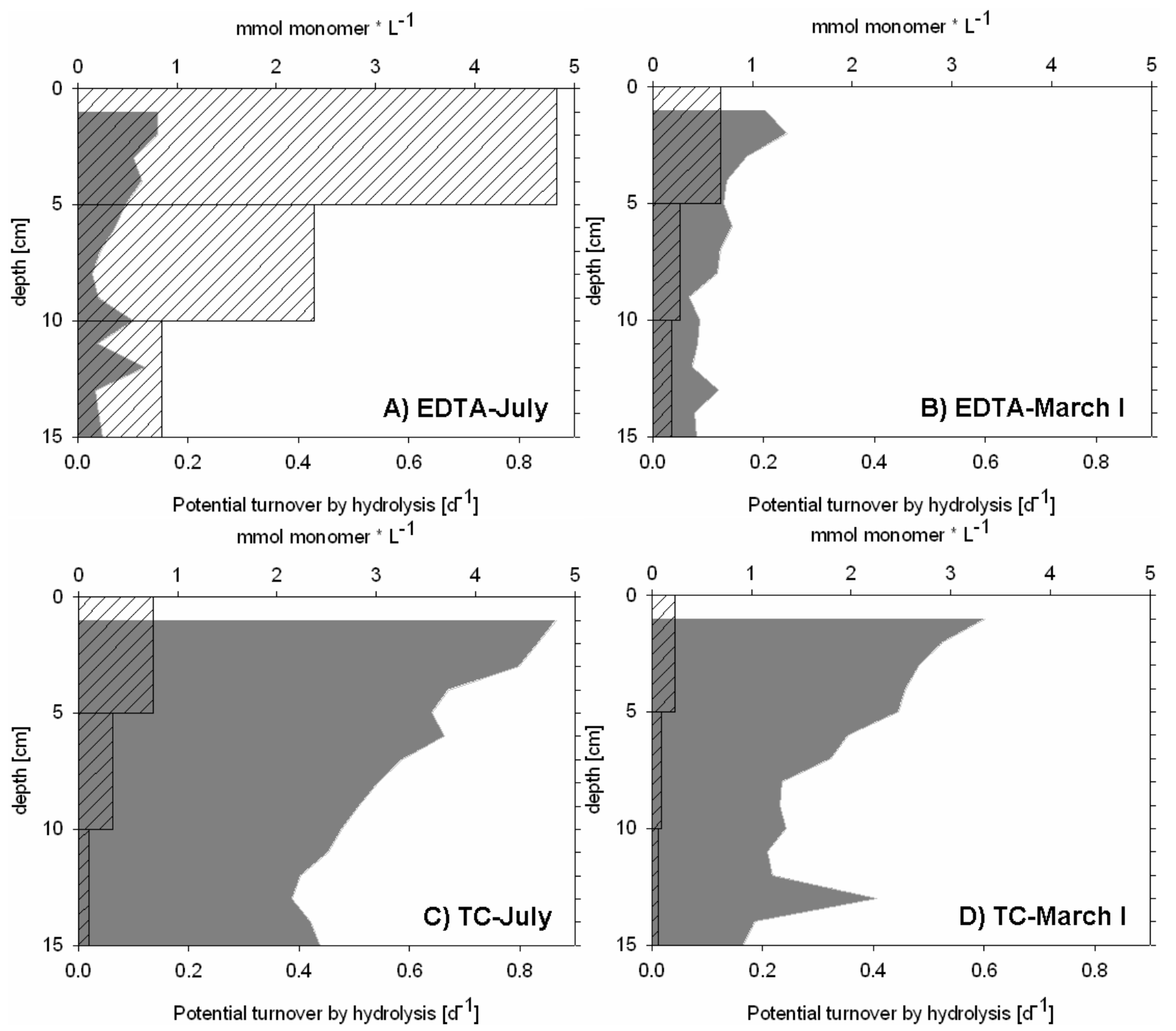

Fig. 5. Potential turnover of (A) EDTA-extractable carbohydrates in July 2005 (B) EDTA-extractable carbohydrates in March I 2006 (C) total carbohydrates in July 2005 and (D) total carbohydrates in March I 2006 in sediment from the Hausstrand. Average carbohydrate concentrations are shown as shaded area; bars represent turnover times based on the sum of laminarinase, $\alpha$-glucosidase, $\beta$-glucosidase and chitobiase activities.

$50 \%$ ), the MPB biomass (on average $1200 \mathrm{mmol} \mathrm{C} \mathrm{m}^{-2} \mathrm{~d}^{-1}$ ) could be turned over in 12 days (neglecting a potential input of pelagic phytodetritus of max. a third of MPB during spring bloom situations; de Beer et al. 2005). On average during the investigated period, in the $0-10 \mathrm{~cm}$ interval, bacterial biomass was $300 \mathrm{mmol} \mathrm{C} \mathrm{m}^{-2}$. Based on a gross bacterial carbon production (BCP) of $60 \mathrm{mmol} \mathrm{C} \mathrm{m}^{-2} \mathrm{~d}^{-1}$, turnover time of the bacterial biomass was 5-6 days. The MPB: bacterial $\mathrm{C}$ ratio was approximately $3: 1$ which is consistent with the results of Evrard et al. (2008), who estimated for the Hausstrand site that living MPB account on average for about $30 \%$ of the total organic carbon pool, while bac- teria, meio- and macrofauna contribute 6,2 and $0.5 \%$ of the total organic carbon pool, respectively. Total carbohydrate concentrations were on average $2000 \mathrm{mmol} \mathrm{C} \mathrm{m}^{-2}$, of which ca. $20 \%$ were EDTA-extractable carbohydrates. Summing up MPB biomass, bacterial biomass and total carbohydrates (taking into account that up to ca. $30 \%$ of algal biomass consist of carbohydrates that are already included in the total carbohydrate pool), and neglecting faunal biomass and organic matter other than carbohydrates, yields a carbon pool of around $3200 \mathrm{mmol} \mathrm{C} \mathrm{m}^{-2}$,

The bacterial carbon production rates of $0.4-$ $2.3 \mathrm{mmolC} \mathrm{L}^{-1} \mathrm{~d}^{-1}$ (for the upper $0-5 \mathrm{~cm}$ ) measured 


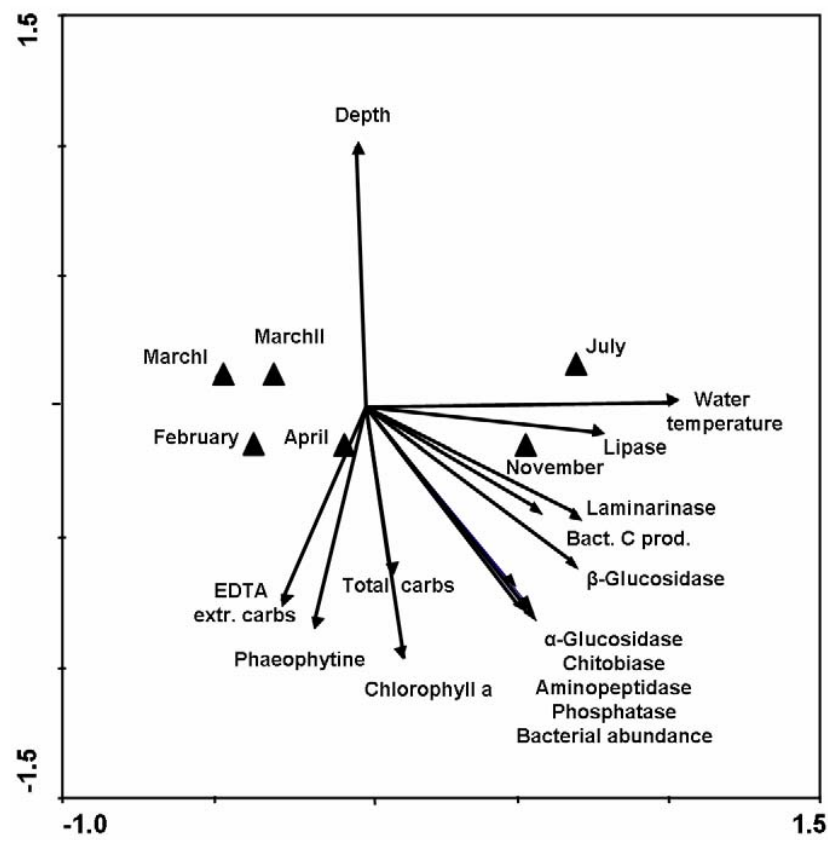

Fig. 6. PCA- (Principal component analysis) plot of major environmental variables at the Hausstrand based on an orthogonal linear transformation method. The magnitude of variation between the variables is depicted in a two-dimensional space. The plot represents $98 \%$ of the original variation in the data; axis 1 and 2 explain $76 \%$ and $22 \%$ of this variation, respectively.

at Hausstrand are well within the range of rates measured in other, more organic-rich areas of the North Sea (van Duyl and Kop, 1990, 1994; van Duyl et al., 1993) and in the productive Great Barrier Reef sands (Alongi, 1992). Assuming a bacterial growth yield (carbon assimilation efficiency) of $50 \%$, as is commonly used for heterotrophic benthic bacteria in surface sediments (Moriarty et al., 1985), the average total bacterial $\mathrm{C}$ demand is $120 \mathrm{mmol} \mathrm{C} \mathrm{m}^{-2} \mathrm{~d}^{-1}$ (peaking in summer with up to $360 \mathrm{mmol} \mathrm{C} \mathrm{m}^{-2} \mathrm{~d}^{-1}$ ). On average, this demand could be covered by a daily turnover of $30 \%$ of the EDTA extractable carbohydrates (in summer up to $125 \%$ ), $6 \%$ of the total carbohydrates or $11 \%$ of the MPB biomass. The sum of the measured potential hydrolytic activities seems to meet this carbon demand. On average, potential extracellular enzymatic hydrolysis of carbohydrates could supply approximately $110 \%$ of the total bacterial $\mathrm{C}$ demand, as calculated from the combined action of chitobiase, $\alpha$-glucosidase, $\beta$-glucosidase and laminarinase acitivities (Table 2). Since laminarinase activities in the surface layer were most likely underestimated, hydrolysis of carbohydrates could even provide more $\mathrm{C}$ than estimated here. Hence, our calculations support the general assumption that EPS could provide most of the substrate required for microbial metabolism (MacIntyre et al., 1996; Underwood and Kromkamp, 1999), but other substrate sources are also available (e.g. DOC, proteinaceous materials), and the
Table 3. $\mathrm{Q}_{10}$-values of exoacting extracellular enzymes as determined experimentally with Hausstrand sediment. Hydrolysis rates of the respective MUF- and MCA-substrates were measured at $4{ }^{\circ} \mathrm{C}$, $16^{\circ} \mathrm{C}$ and $25^{\circ} \mathrm{C}$. Values represent the increase in enzymatic activity when temperature rises by $10^{\circ} \mathrm{C}$.

\begin{tabular}{lc}
\hline Enzyme & $\mathrm{Q}_{10}$-value \\
\hline$\beta$-Glucosidase & 1.7 \\
Lipase & $\mathrm{N} . \mathrm{A}$. \\
Aminopeptidase & 1.4 \\
Phosphatase & 1.4 \\
$\alpha$-Glucosidase & 1.7 \\
Chitobiase & 1.6 \\
\hline
\end{tabular}

activities of enzymes not measured in this study may also play a critical role in microbial nutrition.

\subsection{Vertical zonation of bacterial abundances and activities}

The strong hydrodynamic forces at the Hausstrand lead to frequent lateral transport and vertical mixing of the upper $5 \mathrm{~cm}$ of sediment (Hedtkamp, 2005). In addition, bioirrigation/bioturbation by benthic fauna can mix the upper $10 \mathrm{~cm}$ of sediment (Huettel et al., 2003). Therefore, we can assume that the top $5 \mathrm{~cm}$ are constantly flushed with oxygen-rich water and include considerable amounts of diatom-derived labile organic carbon, while the $5-10 \mathrm{~cm}$ layer is less frequently mixed, and the $10-15 \mathrm{~cm}$ layer remains relatively undisturbed and is dominated by diffusive solute transport. This picture is supported by the physical characteristics of the sediment. The upper $5 \mathrm{~cm}$ of sediment were extremely coarse and yellowish, indicating a zone of strong mixing and oxygenation. The middle layer was greyish and more compact, indicating a transition zone between this oxygen-rich top layer and the diffusion-dominated, deepest layer that was blackish, smelled faintly of sulfide, and contained also smallgrained sediments.

Seasonal and short-term changes in wind stress have been shown to influence sediment permeability (Hedtkamp, 2005); thus storm impacts include increased horizontal and vertical sediment mixing. Despite these active physical dynamics of tides and wave forces at the field site, on all sampling dates (including April and November, with strong storm events) distinct depth trends were evident in MPB biomass, chlorophyll $a$, and phaeopigments, total carbohydrates and EDTA extractable carbohydrates, as well as in bacterial abundances, growth rates, and extracellular enzymatic activities. Concurrent decreases with depth in hydrolytic activities, bacterial abundances, and bacterial carbon production rates suggest a vertical shift in the availability and nutritional quality of organic matter in the sediment. 
Table 4. Pearson correlation coefficients at the Bonferroni-corrected level. Data comprises all samples that included carbohydrate measurements.

\begin{tabular}{llllllllllllllll}
\hline & Depth & Temp & Chl a & Phaeo & Lam & $\alpha$-glu & $\beta$-glu & Chito & Phos & Lip & Pep & Abd & C prd & EDTA & Total \\
\hline Depth & & 0.887 & 0.000 & 0.000 & 0.108 & 0.001 & 0.014 & 0.006 & 0.000 & 0.664 & 0.001 & 0.001 & 0.073 & 0.002 & 0.014 \\
Temp. & 0.040 & & 0.865 & 0.333 & 0.010 & 0.052 & 0.004 & 0.098 & 0.065 & 0.000 & 0.056 & 0.070 & 0.014 & 0.260 & 0.963 \\
Chl a & $*-\mathbf{0 . 9 6 8}$ & 0.048 & & 0.000 & 0.069 & 0.000 & 0.007 & 0.007 & 0.000 & 0.592 & 0.000 & 0.000 & 0.081 & 0.012 & 0.014 \\
Phaeo & $*-\mathbf{0 . 8 1 9}$ & -0.268 & $* \mathbf{0 . 7 9 8}$ & & 0.270 & 0.093 & 0.219 & 0.056 & 0.014 & 0.677 & 0.032 & 0.006 & 0.493 & 0.004 & 0.000 \\
Lam. & -0.431 & 0.644 & 0.481 & 0.305 & & 0.002 & 0.000 & 0.000 & 0.001 & 0.001 & 0.002 & 0.005 & 0.009 & 0.780 & 0.269 \\
$\alpha$-gluc. & -0.763 & 0.511 & 0.787 & 0.449 & 0.741 & & 0.000 & 0.000 & 0.000 & 0.010 & 0.000 & 0.000 & 0.000 & 0.073 & 0.138 \\
$\beta$-gluc. & -0.616 & 0.691 & 0.663 & 0.337 & $* \mathbf{0 . 8 0 2}$ & $* \mathbf{0 . 9 5 5}$ & & 0.000 & 0.000 & 0.001 & 0.000 & 0.000 & 0.000 & 0.240 & 0.120 \\
Chito. & -0.677 & 0.443 & 0.664 & 0.503 & $* \mathbf{0 . 8 3 2}$ & $* \mathbf{0 . 8 8 7}$ & $* \mathbf{0 . 8 3 3}$ & & 0.000 & 0.007 & 0.000 & 0.001 & 0.001 & 0.094 & 0.181 \\
Phos. & $*-\mathbf{0 . 8 1 0}$ & 0.488 & $* \mathbf{0 . 8 2 9}$ & 0.617 & 0.758 & $* \mathbf{0 . 9 4 4}$ & $* \mathbf{0 . 9 2 4}$ & $* \mathbf{0 . 8 7 2}$ & & 0.017 & 0.000 & 0.000 & 0.001 & 0.074 & 0.019 \\
Lip. & -0.122 & $* \mathbf{0 . 8 7 8}$ & 0.151 & -0.117 & 0.749 & 0.638 & 0.755 & 0.660 & 0.603 & & 0.031 & 0.046 & 0.000 & 0.597 & 0.898 \\
Pep. & -0.783 & 0.503 & $* \mathbf{0 . 8 5 2}$ & 0.553 & 0.732 & $* \mathbf{0 . 9 3 4}$ & $* \mathbf{0 . 9 3 3}$ & $* \mathbf{0 . 7 9 9}$ & $* \mathbf{0 . 9 5 2}$ & 0.558 & \\
Abund. & -0.776 & 0.480 & $* \mathbf{0 . 8 3 4}$ & 0.677 & 0.689 & $* \mathbf{0 . 8 4 2}$ & $* \mathbf{0 . 8 4 8}$ & 0.760 & $* \mathbf{0 . 9 3 6}$ & 0.523 & $* \mathbf{0 . 9 2 4}$ & 0.000 & 0.002 & 0.143 & 0.033 \\
C prd & -0.475 & 0.620 & 0.464 & 0.192 & 0.645 & $* \mathbf{0 . 7 9 5}$ & $* \mathbf{0 . 8 2 0}$ & 0.744 & 0.743 & $* \mathbf{0 . 8 3 3}$ & 0.725 & 0.686 & 0.005 & 0.095 & 0.004 \\
EDTA & -0.734 & -0.310 & 0.631 & 0.696 & 0.079 & 0.475 & 0.323 & 0.448 & 0.474 & -0.149 & 0.397 & 0.447 & 0.240 & 0.389 & 0.488 \\
Total & -0.617 & -0.013 & 0.620 & $* \mathbf{0 . 7 9 5}$ & 0.305 & 0.401 & 0.419 & 0.365 & 0.595 & -0.036 & 0.551 & 0.693 & 0.194 & 0.637 & 0.011 \\
\hline
\end{tabular}

Pearson correlation coefficients calculated on standardized data are shown in the lower left part of the table. $P$-values of correlations are shown in the upper right part of the table; *denotes significant coefficients at the Bonferroni-corrected level $(p \leq 0.05 / 105=0.000476)$ which are additionally shown in bold for better visualization.

Abbreviations: Temp=temperature, Chl $a$ =benthic chlorophyll $a$, Phaeo=benthic phaeophytine, $\alpha$-glu. $=\alpha$-glucosidase, $\beta$-glu= $\beta$ glucosidase , Chito = chitobiase, Phos = phosphatase, $\mathrm{Lip}=$ Lipase, $\mathrm{Pep}=$ Aminopeptidase, $\mathrm{Abd}=$ bacterial abundance, $\mathrm{C}$ prd $=$ bacterial car bon production, $\mathrm{EDTA}=$ EDTA-extractable carbohydrates, Total $=$ Total carbohydrates .

Bacterial abundances were statistically correlated to hydrolytic activities of $\alpha$-glucosidase, $\beta$-glucosidase, phosphatase and aminopeptidase ( $r$ between 0.84 and 0.94 , $p<0.00024$; Table. 4), partially explaining the decrease in hydrolytic activities with depth. But even cell-specific hydrolytic enzyme activities showed a distinct decrease with depth, presumably due to the reduced availability and quality of organic substrates. This is also consistent with the lower turnover of carbohydrates with depth (Fig. 5), and the depthrelated decrease in BCP. Similar depth trends have been reported from muddy sediment sites, where particulate organic matter mixing into the sediment depends entirely on bioturbation (e.g. Mayer, 1989; Arnosti, 1995). However, distinct depth trends in highly dynamic sandy environments are unusual. In Middle Atlantic Bight shelf sediments, a site quite comparable to Hausstrand, Rusch and coworkers (2003) investigated depth-related and seasonal patterns in bacterial and algal cell abundances, exoenzymatic activities and carbon inventory. The bacterial community was found to be highly active, with aminopeptidase and $\beta$-glucosidase activities comparable to those measured in the present study; however depth-related patterns were only found during the winter sampling date. Likewise, an investigation of aminopeptidase, $\beta$-glucosidase, alkaline phosphatase activities, their natural substrates, bacterial abundances and biomass in two adjacent areas of a sandy beach over one year showed a lack of vertical patterns within the top $15 \mathrm{~cm}$ (Misic and Harriague, 2007). An intertidal sandy area close to our sampling site (Musat et al., 2006) also did not reveal the pronounced depthrelated changes in bacterial abundances that we found in the subtidal sediments. We assume that the observed depth gradient is mainly due to the distribution of the MPB and the biofilm-like association with the bacterial community. This is supported by the tight correlation between bacterial abundances and benthic chlorophyll $a(r=0.83, p<0.00024)$. At Hausstrand, most of the benthic diatom biomass is found in the top $0-5 \mathrm{~cm}$ layer, but moderately high concentrations could be observed down to a depth of $-8 \mathrm{~cm}$, corresponding to the maximal depth of advective transport. At these depths, diatoms are non-active, but able to survive several months without loosing their photosynthetic capacity (Sundbäck and Granéli, 1988; Nelson et al., 1999).

\subsection{Temperature-related temporal patterns in bacterial activities}

Water temperature followed a typical seasonal pattern over the sampling period (Fig. 2a), with winter temperatures close to the freezing point and summer temperatures of up to $20^{\circ} \mathrm{C}$. The spring bloom in the water column of Sylt occurs generally in April (van Beusekom et al., 2009), but even at the peak of phytoplankton biomass, the integrated carbon concentrations were $<7 \%$ of the microphytobenthic standing stock in the sands. Although the temporal variation of the MPB and bacterial standing stock was negligible, the entire benthic community was more active at higher temperatures as indicated by the pattern of total benthic oxygen consumption (Fig. 2b). Extracellular enzymatic activities and bacterial carbon production clearly also followed the temperature trend (Fig. 2c, d) and reached maximum values in July. The lack of temporal variation in MPB and bacterial biomass 
(Fig. 2c) contrasted with the changes in activity patterns, and may be due to higher grazing pressure in the summer. Likewise, the lack of a temperature-related pattern in carbohydrate concentrations (Fig. 4) could reflect higher bacterial consumption during times of higher MPB production, since carbohydrate concentrations reflect the net balance between production and consumption.

Higher enzymatic hydrolysis rates may be the result of faster enzyme function and/or of enhanced bacterial enzyme synthesis at higher temperatures. High BCP rates and high benthic oxygen consumption in July provide evidence for a generally enhanced metabolism in summer. Apparent temperature effects on hydrolytic exoenzyme activities at the Hausstrand experimentally yielded $\mathrm{Q}_{10}$ values between 1.4 and 1.7 (Table 3), indicating that temperature effects could cause an increase in the activity of enzymes only by less than a factor of 2 when temperature rises by $10^{\circ} \mathrm{C}$. In the field, a much higher increase of enzyme acivities was observed between winter and summer, suggesting that enzyme synthesis by the benthic bacteria may have changed, possibly due to induction by increased substrate availability in the summer months. Moreover, temperature between July and November dropped by only $7^{\circ} \mathrm{C}$ while EEA decreased by a factor of up to 5. Temperature has also been found to be an important but not the only factor affecting seasonal variations in extracellular proteolytic enzyme activity in an intertidal mudflat (Mayer, 1989). Since bacterial abundances do not necessarily reflect the state of activity of the microbial community (Créach et al., 2003) and no information is available on variations in the fraction of the community producing specific enzymes, changes in bacterial community structure and composition may also have influenced seasonal changes in hydrolytic rates.

The microphytobenthic standing stock - as derived from chlorophyll $a$ - at Hausstrand was generally stable over the entire sampling period, except for minor peaks in spring, in accordance with observations in other shallow sediment ecosystems (Varela and Peñas, 1985; Goto et al., 1998; Goto et al., 2000). The significant temporal changes in microbial activities thus can best be explained by a combination of the effects of temperature and substrate availability. The minor temporal variations in microbial and MPB biomass are typical for biofilm-type communities; they could result from light and space limitation as well as from extensive grazing pressure. Previous investigations suggested that especially the nano- and meiofauna play an important role in the removal of bacterial and MPB biomass in permeable sands (Epstein, 1997; Cahoon, 1999; Middelburg et al., 2000; Urban-Malinga et al., 2006; Evrard et al., 2008).
Acknowledgements. Susanne Menger is gratefully acknowledged for assistance in the field and with sample processing. Stefanie I. C. Hedtkamp kindly provided 2005 benthic respiration data. Sherif Gobrial is thanked for the GPC analysis of potential endoenzymatic activities and Gabriele Schüßler is recognized for assistance with ${ }^{3} \mathrm{H}$-thymidine incorporation measurements. Hannelore Halliger and Reimer Magens supported our work on Sylt logistically and technically. The scientific divers Christian Buschbaum and Patrick Polte are gratefully acknowledged for recovery of sediments samples in April 2005 and November 2005. Aerial photo material was kindly provided by the Wadden Sea National Park Office. This study was financed by the Max Planck society. CA received funding from the National Science Foundation (OCE-0323975 and -0848703), as well as support from the Hanse Institute for Advanced Study and the Alfred Wegener Institute for Polar and Marine Research while the manuscript was being written.

The service charges for this open access publication have been covered by the Max Planck Society.

Edited by: S. W. A. Naqvi

\section{References}

Alderkamp, A. C., van Rijssel, M., and Bolhuis, H.: Characterization of marine bacteria and the activity of their enzyme systems involved in degradation of the algal storage glucan laminarin, FEMS Microbiol. Ecol., 59(1), 108-117, 2006.

Alongi, D. M.: Vertical profiles of bacterial abundance, productivity and growth rates in coastal sediments of the central Great Barrier Reef lagoon, Mar. Biol., 112, 657-663, 1992.

Arnosti, C.: Measurement of depth- and site-related differences in polysaccharide hydrolysis rates in marine sediments, Geochim. Cosmochim. Acta, 59(20), 4247-4257, 1995.

Arnosti, C. and Holmer, M.: Carbon cycling in a continental margin sediment: contrasts between organic matter characteristics and remineralization rates and pathways, Est. Coast. Shelf Sci., 58, 197-208, 2003.

Arnosti, C.: Fluorescent Derivatization of Polysaccharides and Carbohydrate-Containing Biopolymers for Measurement of Enzyme Activities in Complex Media. J. Chromatog. B, 793, 181191, 2003.

Arnosti, C. and Jørgensen B. B.: Organic carbon degradation in Arctic marine sediments, Svalbard: A comparison of initial and terminal steps, Geomicrobiol. J., 23, 551-563, 2006.

Asmus, R. M., Jensen, M. H., Murphy, D., and Doerffer, R.: Primary Production of Microphytobenthos, in: Phytoplankton and the Annual Yield of Macrophytic Biomass in the Sylt-Røm $\varnothing$ Wadden Sea, edited by: Gätje, C. and Reise, K., Ökosystem Wattenmeer, Springer Verlag, Berlin, Germany, 1998.

Billerbeck, M., Røy, H., Bosselmann, K., and Huettel, M.: Benthic photosynthesis in submerged Wadden Sea intertidal flats, Est. Coast. Shelf Sci., 71(3-4), 704-716, 2007.

Boetius, A.: Microbial hydrolytic enzyme activities in deep-sea sediments, Helgoländer Meeresuntersuchungen, 49, 177-187, 1995.

Boetius, A. and Lochte, K.: Effect of organic enrichments on hydrolytic potentials and growth of bacteria in deep-sea sediments, Mar. Ecol. Prog. Ser., 140, 239-250, 1996a. 
Boetius, A. and Lochte, K.: High proteolytic activities of deepsea bacteria from oligotrophic polar sediments, Arch. Hydrobiol. Spec. Issues, Adv. Limnol., 48, 269-276, 1996 b.

Boudreau, B.P., Huettel, M., Forster, S., Jahnke, R.A., McLachlan, A., Middelburg, J.J., Nielsen, P., Sansone, P., Taghon, G., Van Raaphorst, W., Webster, I., Weslawski, J.M., Wiberg, P., Sundby, B.: Permeable marine sediments: Overturning an old paradigm, EOS, 82, 135-136, 2001.

Cahoon, L. B.: The role of benthic microalgae in neritic ecosystems, edited by: Ansell, A. D., Gibson, R. N., and Barnes, M., Oceanogr. Mar. Biol. Ann. Rev., 37, Taylor \& Francis, London, 47-86, 1999.

Canfield, D. E., Jørgensen, B. B., Fossing, H., Glud, R., Gundersen, J., Ramsing, N. B., Thamdrup, B., Hansen, J. W., Nielsen, L. P., and Hall, P. O. J.: Pathways of organic carbon oxidation in three continental margin sediments, Marine Geol., 113, 27-40, 1993.

Cook, P. L. M., Veuger, B., Böer, S., and Middelburg, J. J.: Effect of nutrient availability on carbon and nitrogen incorporation and flows through benthic algae and bacteria in near-shore sandy sediment, Aquat. Microb. Ecol., 40, 165-180, 2007a.

Cook, P. L. M., Wenzhöfer, F., Glud, R. N., Janssen, F., and Huettel, M.: Benthic solute exchange and carbon mineralization in two shallow subtidal sandy sediments: Effect of advective pore-water exchange, Limnol. Oceanogr., 52(5), 1943-1963, 2007b.

Cramer, A.: Seasonal variation in benthic metabolic activity in a frontal system in the North Sea,, in: Trophic relationships in the marine environment 1990, edited by: Barnes, M. and Gibson, R. N. Proc. 24th Europ. Mar. Biol. Symp., University Press Aberdeen, UK, 54-76, 1990.

Créach, V., Baudoux, A. C., Bertru, G., and Le Rouczic, B.: Direct estimate of active bacteria: CTC use and limitations, J. Microbiol. Methods., 52(1), 19-28, 2003.

D'Andrea, A. F., Aller, R. C., and Lopez, G. R.: Organic matter flux and reactivity on a South Carolina sandflat: The impacts of porewater advection and macrobiological structures, Limnol. Oceanogr., 47, 1056-1070, 2002.

D'Andrea, A. F. D., Lopez, G. R., and Aller, R. C.: Rapid physical and biological particle mixing on an intertidal sandflat, J. Mar. Res., 62, 67-92, 2004.

de Beer, D., Wenzhöfer, F., Ferdelman, T. G., Boehme, S. E., Huettel, M., van Beusekom, J. E. E., Böttcher, M. E., Musat, N., and Dubilier, N.: Transport and mineralization rates in North Sea sandy intertidal sediments, Sylt-Røm ø Basin, Wadden Sea, Limnol. Oceanogr., 50(1), 113-127, 2005.

de Brouwer, J. F. C. and Stal, L. J.: Short-term dynamics in microphytobenthos distribution and associated extracellular carbohydrates in surface sediments of an intertidal mudflat, Mar. Ecol. Prog. Ser., 218, 33-44, 2001.

Dubois, M., Gilles, K. A., Hamilton, J. K., Rebers, P. A., and Smith, F.: Colorimetric method for determination of sugars and related substances, Anal. Chem., 28, 350-356, 1956.

Emery, K. O.: Relict sediments on continental shelves of the world, AAPG Bulletin, 52, 445-464, 1968.

Epstein, S. S.: Microbial food webs in marine sediments. I. Trophic interactions and grazing rates in two tidal flat communities, Microb. Ecol., 34, 188-198, 1997.

Evrard, V. P. E., Cook, P. L. M., Veuger, B., Huettel, M., and Middelburg, J. J.: Tracing carbon and nitrogen incorporation and pathways in the microbial community of a photic subtidal sand,
Aquat. Microb. Ecol., 53, 257-269, 2008.

Findley, S. E. G., Meyer, J. L., and Edwards, R. T.: Measuring bacterial production via rate of incorporation of $\left[{ }^{3} \mathrm{H}\right]$ thymidine into DNA, J. Microbiol. Meth., 2, 57-72, 1984.

Findley, S. E. G.: Thymidine incorporation into DNA as an estimate of sediment bacterial production, in: Handbook of methods in aquatic microbial ecology, edited by: Kemp, P. F., Sherr, B. F., Sherr, E. B., and Cole, J. J., Lewis publishers, Baton Rouge, 505508, 1993.

Fuhrman, J. A. and Azam, F.: Thymidine incorporation as a measure of heterotrophic bacterioplankton production in marine surface waters: evaluation and field results, Mar. Biol., 66, 109-120, 1982.

Gätje, C. and Reise, K.: Ökosystem Wattenmeer: Austausch, Transport und Stoffwandlungsprozesse, Springer Verlag, Berlin, Heidelberg, Germany, 570 pp., 1998.

Gattuso, J. P., Gentili, B., Duarte, C. M., Kleypas, J. A., Middelburg, J. J., and Antoine, D.: Light availability in the coastal ocean: impact on the distribution of benthic photosynthetic organisms and their contribution to primary production, Biogeosciences, 3, 489-513, 2006, http://www.biogeosciences.net/3/489/2006/.

Glabe, C. G., Harty, P. K., and Rosen, S. D.: Preparation and properties of fluorescent polysaccharides, Anal. Biochem., 130, 287 294, 1983.

Goto, N., Mitamura, O., Terai, H., and Ishida, N.: Physicochemical features and primary production of microphytobenthos and phytoplankton at Wakaura tidal flat in Japan, Jpn. J. Limnol., 59, 391-408, 1998.

Goto, N., Mitamura, O., and Terai, H.: Seasonal variation in primary production of microphytobenthos at the Isshiki intertidal flat in Mikawa Bay, Jpn. J. Limnol., 1, 133-138, 2000.

Goto, N., Mitamura, O., and Terai, H.: Bidegradation of photosynthetically produced extracellular organic carbon from intertidal benthic algae, J. Exp. Mar. Biol. Ecol., 257, 73-86, 2001.

Grasshoff, K., Kremling, K., and Ehrhardt, M.: Methods of seawater analysis, Wiley-VHC, Berlin, Germany, p. 419, 1983.

Hall, S. J.: The continental shelf benthic ecosystem: current status, agents for change and future prospects, Environ. Conserv., 29, 350-374, 2002.

Hedtkamp, S. I. C.: Shallow subtidal sand: Permeability, nutrient dynamics, microphytobenthos and organic matter, Dissertation thesis, Christian-Albrechts-Universität Kiel, Germany, 2005.

Heip, C., Huys, R., Vincx, M., Vanreusel, A., Smol, N., Herman, R., et al.: Composition, distribution, biomass and production of North Sea meiofauna, Neth. J. Sea Res., 26(2-4), 333-342, 1990.

Herbert, D., Phipps, P. J., and Strange, R. E.: Chemical analysis of microbial cells, in: Methods in microbiology, edited by: Norris, J. R. and Ribbons, D. W., Academic Press, London, UK, 209344, 1971.

Hoagland, K. D., Rosowski, J. R., Gretz, M. R., and Roerner, S. C.: Diatom extracellular polymeric substances: function, fine structure, chemistry and physiology, J. Phycol., 29(5), 537-566, 1993.

Hobbie, J. E., Daley, R. J., and Jasper, S.: Use of nuclepore filters for counting bacteria by fluorescence microscopy, Appl. Environ. Microbiol., 33(5), 1225-1228, 1977.

Hoppe, H. G.: Significance of exoenzymatic activities in the ecology of brackish water: measurements by means of methylumbelliferyl-substrates, Mar. Ecol. Prog. Ser., 11, 299- 
308, 1983.

Hoppe, H. G., Kim, S. J., and Gocke, K.: Microbial decomposition in aqutic environments: combined process of extracellular enzyme activity and substrate uptake, Appl. Environ. Microbiol., 54, 784-790, 1988.

Hoppe, H. G., Arnosti, C., and Herndl, G. F.: Ecological Significance of bacterial enzymes in the marine environment, edited by: Burns, R. G., Dick, R. P., Templeton, D. M., in: Enzymes in the environment: activity, ecology, and applications, CRC Press, 73-108, 2002.

Huettel, M., Røy, H., Precht, E., and Ehrenhauss, S.: Hydrodynamical impact on biogeochemical processes in aquatic sediments, Hydrobiologia, 49, 231-236, 2003.

Jahnke, R. A.: Transport processes and organic matter cycling in coastal sediments, Robinson, A. R. and Brink, K. H., in: The Sea, 13, 163-192, 2004.

Lee, R. E.: Phycology, Cambridge University Press, Cambridge, 1980.

Loebl, M., Dolch, T., and van Beusekom, J. E. E.: Annual dynamics of pelagic primary production and respiration in a shallow coastal basin, J. Sea Res. 58, 269-282, 2007.

Lorenzen, C. J.: Determination of chlorophyll and pheo-pigments: spectrophotometric equations, Limnol. Oceanogr., 12(2), 343346, 1967.

MacIntyre, H. L., Geider, R. J., and Miller, D. C.: Microphytobenthos: The ecological role of the "secret garden" of unvegetated, shallow-water marine habitats. 1. Distribution, abundance and primary production, Estuaries, 19, 186-201, 1996.

Mayer, L. M.: Extracellular proteolytic enzyme activity in sediments of an intertidal mudflat, Limnol. Oceanogr., 34(6), 973981, 1989.

Meyer-Reil, L. A.: Measurement of hydrolytic activity and incorporation of dissolved organic substrates by microorganisms in marine sediments, Mar. Ecol. Prog. Ser., 31, 143-149, 1986.

Meyer-Reil, L. A.: Seasonal and spatial distribution of extracellular enzymatic activities and microbial incorporation of dissolved organic substrates in marine sediments, Appl. Environ. Microbiol., 53(8), 1748-1755, 1987.

Michel, P. H. and Bloem, J.: Conversion factors for estimation of cell production rates for soil bacteria from $\left[{ }^{3} \mathrm{H}\right]$ thymidine and $\left[{ }^{3} \mathrm{H}\right]$ leucine incorporation, Soil Biol Biochem, 25(7), 943-950, 1993.

Middelburg, J. J., Barranguet, C., Boschker, H. T. S., Herman, P. M. T., Moens, T., and Heip, C. H. R.: The fate of intertidal microphytobenthos carbon: An in situ ${ }^{13} \mathrm{C}$-labeling study, Limnol. Oceanogr., 46(6), 1224-1234, 2000.

Misic, C. and Fabiano, M.: Enzymatic activity on sandy beaches of the Ligurian Sea (NW Mediterranean), Microb. Ecol., 49, 513$522,2005$.

Misic, C. and Harriague, A. C.: Enzymatic activity and organic substrates on a sandy beach of the Ligurian Sea (NW Mediterranean) influenced by anthropogenic pressure, Aquat Microb Ecol, 47, 239-251, 2007.

Moriarty, D. J. W., Pollard, P. C., Hunt, W. G., Moriarty, C. M., and Wassengerg, T.: Productivity of bacteria and microalgae and the effect of grazing by holothurians on a coral reef flat, Mar. Biol., 85, 293-300, 1985.

Moriarty, D. J. W.: Techniques for estimating bacterial growth rates and production of biomass in aquatic environments, in: Meth- ods in microbiology, edited by: Grigorova, R. and Norris, J. K., Academic Press, London, UK, 22, 211-134, 1990.

Moriarty, D. J. W. and Pollard, P. C.: Effects of radioactive labeling of macromolecules, disturbance of bacteria and adsorption of thymidine to sediment on the determination of bacterial growth rates in sediment with tritiated thymidine, J. Microbiol. Methods, 11, 127-139, 1990.

Musat, N., Werner, U., Knittel, K., Kolb, S., Dodenhof, T., van Beusekom, J. E. E., de Beer, D., Dubilier, N., and Amann, R.: Microbial community structure of sandy intertidal sediments in the North Sea, Sylt-Rømø Basin, Wadden Sea, Syst. Appl. Microbiol., 29, 333-348, 2006.

Nelson, J. R., Eckmann, J. E., Robertson, C. Y., Marinelli, R. L., and Jahnke, R. A.: Benthic microalgal biomass and irradiance at the sea floor on the continental shelf of the South Atlantic Bight: Spatial and temporal variability and storm effects, Cont. Shelf Res., 19, 477-505, 1999.

Ortega-Calvo, J. J. and Stal, L. J.: Sulphate-limited growth in the unicellular cyanobacterium Gloethece (Nageli) sp. PCC 6909, New Phytol, 128(2), 273-281, 1994.

Painter, T. J.: Algal Polysaccharides, in: The polysaccharides, edited by: Aspinall, G. O., Academic Press, 195-285, 1983.

Ramette, A.: Multivariate analyses in microbial ecology, FEMS Microbiol. Ecol., 62(2), 142-160, 2007.

Rooney-Varga, J. N., Giewat, M. W., Savin, M. C., Sood, S., LeGresley, M., and Martin, J. L.: Links between phytoplankton and bacterial community dynamics in a coastal marine environment, Microb. Ecol., 49, 163-175, 2005.

Rusch, A., Huettel, M., Reimers, C. E., Taghon, G. L., and Fuller, C. M.: Activity and distribution of bacterial populations in Middle Atlantic Bight shelf sand, FEMS Microbiol. Ecol., 44, 89-100, 2003.

Rusch, A., Huettel, M., Wild, C., Reimers, C.E.: Benthic oxygen consumption ond organic matter turnover in organic-poor, permeable shelf sands, Aquat. Geochem., 12, 1-19, 2006.

Smith, D. J. and Underwood, G. J. C.: Exopolymer production by intertidal epipelic diatoms, Limnol. Oceanogr., 43, 1578-1591, 1998.

Staats, N., de Deckere, E., Kornman, B., van der Lee, W., Termaat, R., Terwindt, J., and de Winder, B.: Oberservations on suspended particulate matter (SPM) and microalgae in the Dollard estuary, the Netherlands: Importance of late winter ice cover of the intertidal flats, Est Coast Shelf Sci, 53, 297-306, 2001 a.

Staats, N., de Deckere, E. M. G. T., de Winder, B., and Stal, L. J.: Spatial patterns of benthic diatoms, carbohydrates and mud on a tidal flat in the Ems-Dollard estuary, Hydrobiologia, 448, 107-115, 2001b.

Strickland, J. D. and Parsons, T. R.: A practical handbook of seawater analysis, Bulletin of Fisheries Research Board of Canada, 2nd ed., p. 167, 1972.

Sundbäck, K. and Granéli, W.: Influence of microphytobenthos on the nutrient flux between sediment and water: a laboratory study, Mar. Ecol. Prog. Ser., 43, 63-69, 1988.

ter Braak, C. J. F. and Šmilauer, P.: CANOCO Reference Manual and CanoDraw for Windows User's Guide: Software for Canocical Community Ordination, Version 4.5, 2002

Thorbergsdttir, I. M., Gíslason, S. R., Ingvason, H. R., and Einarsson, Á.: Benthic oxygen flux in the highly productive subarctic Lake Myvatn Iceland: in situ benthic flux chamber study, 
Aquat. Ecol., 38, 177-189, 2004.

Underwood, G. J. C., Paterson, D. M., and Parkes, R. J.: The measurement of microbial carbohydrate exopolymers from intertidal sediments, Limnol. Oceanogr., 40(7), 1243-1253, 1995.

Underwood, G. J. C. and Kromkamp, J.: Primary production by phytoplankton and microphytobenthos in estuaries, edited by: Nedwell, D. B. and Raffaelli, D., in: Advances in Ecological Research, Vol 29, Academic Press Inc, San Diego, USA, 93-153, 1999.

Underwood, G. J. C. and Paterson, D. M.: The importance of extracellular carbohydrate production by marine epipelic diatoms,, in: Advances in Botanical Research, edited by: Callow, J. A., Advances in Botanical Research Incorporating Advances in Plant Pathology, 40, 183-240, 2003.

Urban-Malinga, B., Hedtkamp, S. I. C., van Beusekom, J. E. E., Wiktor, J., and Weslawski, J. M.: Comparison of nematode communities in Baltic and North Sea sublittoral, permeable sands Diversity and environmental control, Est. Coast. Shelf Sci., 70, 224-238, 2006.

van Beusekom, J. E. E. and Reise, K.: Editorial: Long-term ecological change in the northern Wadden Sea, Helgol. Mar. Res., 62, $1-2,2008$.

van Beusekom, J. E. E., Loebl, M., and Martens, P.: Distant riverine nutrient supply and local temperature drive the long-term phytoplankton development in a temperate coastal basin. J. Sea Res., 61, 26-33, 2009.

van Duyl, F. C. and Kop, A. J.: Seasonal patterns of bacterial production and biomass in intertidal sediments of the western Dutch Wadden Sea, Mar. Ecol. Prog. Ser., 59, 249-261, 1990. van Duyl, F. C., Bak, R. P. M., Kop, A. J., Nieuwland, G., Berghuis, E. M., and Kok, A.: Mesocosm experiments: mimicking seasonal developments of microbial variables in North Sea sediment, Hydrobiologia, 235-236, 267-281, 1992.

van Duyl, F. C., van Raaphorst, W., and Kop, A. J.: Benthic bacterial production and nutrient sediment-water exchange in sandy North Sea sediments, Mar. Ecol. Prog. Ser., 100, 85-95, 1993.

van Duyl, F.C. and Kop, A. J.: Bacterial production in North Sea sediments: clues to seasonal and spatial variations, Mar. Biol., 120, 323-337, 1994.

van Duyl, F. C., de Winder, B., Kop, A. J., and Wollenzien, U.: Tidal coupling between carbohydrate concentrations and bacterial activities in diatom-inhabited intertidal mudflats, Mar. Ecol. Prog. Ser., 191, 19-32, 1999.

van Oevelen, D., Soetaert, K., Middelburg, J. J., Herman, P. M. J., Moodley, L., Hamels, I., Moens, T., and Heip, C. H. R.: Carbon flows through a benthic food web: integrating biomass, isotope and tracer date, J. Mar. Res., 64, 453-482, 2006.

Varela, M. and Penas, E.: Primary production of benthic microalgae in an intertidal sand flat of the Ria de Arosa, NW Spain, Mar. Ecol. Prog. Ser., 25, 111-119, 1985.

Warren, R. A. J.: Microbial hydrolysis of polysaccharides, Ann. Rev. Microbiol., 50, 183-212, 1996.

Winkler, L. W.: Determination of dissolved oxygen in water, Berlin Deut. Chem. Ges., 1888.

Wollast, R.: Continental margins - review of geochemical settlings, in: Ocean margin systems, edited by: Wefer, G., Billet, D., Hebbeln, D., Jørgensen, B. B., Schlüter, M., van Weering, T. C. E., Springer, 2002. 